\title{
Integration of the buyer-supplier interface for Global sourcing
}

\author{
Lydia Bals ${ }^{1,2,3}$. Virpi Turkulainen ${ }^{4}[0$
}

Received: 30 April 2021 / Revised: 8 July 2021 / Accepted: 14 July 2021 / Published online: 31 July 2021

(c) The Author(s) 2021

\begin{abstract}
While global sourcing often implies that the firm needs to, for example, redesign the procurement organization and make decisions on what to centralize and what to manage locally, global sourcing also has direct implications for management of the buyer-supplier interface. This study takes an organization design focus and addresses global sourcing organization design as well as provides illustrations on how to integrate the buyer-supplier interface for global sourcing. Integration is conceptualized as coordination and cooperation. The paper is based on an embedded unit case study of a global technical industrial product and service systems provider, TechInd (pseudonym). Data was collected from TechInd as well as from six of its suppliers. The findings indicate that the global sourcing organization structure, as well as the differences in the buyer's sourcing and supplier's sales organizations, pose requirements for management of the interface in terms of coordination and cooperation. Challenges arising particularly due to differences in geographical scope and level of centralization can be managed by introducing the key account role and alignment of incentives.
\end{abstract}

Keywords Global sourcing · Buyer-supplier relationship · Integration · Organizational design · Case study · Project-based operations

\section{Introduction}

Along with the increasing strategic role and importance of purchasing and supply management (Capon and Senn 2010; Faes et al. 2000; Foerstl et al. 2013; Gadde and Snehota 2000), contemporary companies continue to increase global sourcing of goods and services (Jia et al. 2014; Schleper et al. 2020). Global sourcing ${ }^{1}$ implies that the firm often needs to, for example, redesign the procurement organization and make decisions on what to centralize and what to manage locally (Bals and Turkulainen 2017). Hence, moving towards global sourcing poses organizational implications to the focal firm (Bals and Turkulainen 2017; Jia et al. 2014; Luzzini et al. 2014; Trautmann et al. 2009b), and subsequently, global

Lydia Bals

lydia.bals@hs-mainz.de

1 Mainz University of Applied Sciences, Lucy-Hillebrand-Str. 2, 55128 Mainz, Germany

2 EBS University for Business and Law, Oestrich-Winkel, Germany

3 Copenhagen Business School (CBS), Copenhagen, Denmark

4 Haaga-Helia University of Applied Sciences, Helsinki, Finland sourcing directly affects the buyer-supplier interface (Horn et al. 2014; Vanpoucke et al. 2014; Wieland et al. 2020).

The purpose of this study is to develop further understanding of how to integrate the buyer-supplier interface for global sourcing. Global sourcing poses direct managerial challenges as follows. First, global sourcing often means a significant reduction in the supplier base, sometimes as much as by 70 to 90 percent (Capon and Senn 2010), requiring additional strategic intent and attention from buyers and suppliers. Moreover, the suppliers need to market and sell their products and services for the same buyer on a global scale, while addressing potential local variations (Capon and Senn 2010; Swoboda et al. 2012). Finally, aligning the buyer and supplier organization structures might be needed to facilitate effective management of the buyer-supplier relationship (BSR) (Capon and Senn 2010; Guesalaga et al. 2018; Homburg et al. 2000; Toulan et al. 2006), representing an area in need for more research (Guesalaga et al. 2018).

\footnotetext{
1 'Global sourcing' refers to the worldwide integration of engineering, operations, and procurement centers, looking for common items, processes, design, technologies, knowledge, and suppliers across functions and locations (Kotabe and Murray 2004; Trent and Monczka 2003a, 2005). Prior research has used terms such as 'global purchasing' (Trent and Monczka 2003b) and 'international purchasing' (Quintens et al. 2006) as synonymous for the same concept.
} 
While there is research on global sourcing organization design (e.g. Bals and Turkulainen 2017; Jia et al. 2017; Johnson and Leenders 2001; Narasimhan and Carter 1990), it has mainly addressed the design of the sourcing organization only, paying less attention to the buyer-supplier interface and its management. However, integration of the BSR is one of the fundamental issues in management of the interface (Kaipia and Turkulainen 2017; Sheth and Sharma 1997; Terpend et al. 2008) and it is particularly critical for global sourcing: as stated by Capon and Senn (2010, p. 35f.), "a traditional multinational supplier cannot satisfy the needs of a multinational customer that globalizes its procurement, even though both firms operate in similar countries around the world [so] the reality is very clear: for multinational suppliers to survive and grow in the twenty-first century, they must make the necessary investments to address the challenges of multinational customers that are globalizing their procurement operations". In our study, we address this phenomenon and pursue the following research question: How to integrate the buyer-supplier interface for global sourcing? We take an organization design perspective and build on Gulati et al. (2005) defining integration as consisting of coordination and alignment of actions (Burton et al. 2006; Galbraith 1973) as well as cooperation and alignment of interests (Yan and Dooley 2013). We analyze empirical data collected from a globally operating firm TechInd (pseudonym), which is a provider of technical industrial product and service systems, as well as from six of its tier- 1 suppliers.

Our study provides an illustration of contemporary global sourcing organizational design (Bals and Turkulainen 2017; Jia et al. 2017). We also complement research on BSRs and integration in the buyer-supplier interface in a generic sourcing setting (Ambrose et al. 2008; Revilla and Knoppen 2015; Turkulainen et al. 2017; Vanpoucke et al. 2014), going beyond the implications that global sourcing has on the buyer's organization (Giunipero and Monczka 1997; Jia et al. 2014; Johnson and Leenders 2001; Luzzini et al. 2014; Narasimhan and Carter 1990; Schneider and Wallenburg 2013; Trautmann et al. 2009b). This way our study also provides insight into the calls for research on the interdependence between buyer-supplier organization structures (Bals and Turkulainen 2017; Guesalaga et al. 2018; Toulan et al. 2006) and on the inter-organizational interface in global sourcing (Wieland et al. 2020). The empirical study takes place in the project operations context, which is increasingly characteristic to operations environment (Maylor and Turkulainen 2019) and yet poses additional managerial challenges due to uniqueness and temporal nature of the operations (Burke and Morley 2016; Lundin and Söderholm 1995).

\section{Global sourcing and the buyer-supplier interface}

We use the term organizational design for the 'organization structure' (i.e. division of tasks and responsibilities) as well as for the 'processes' of managing the organizational interfaces (Mintzberg 1983). These processes are coordination and cooperation as the constituents of integration (Galbraith 1973; Gulati et al. 2005; Lawrence and Lorsch 1967; Yan and Dooley 2013), the concept which we elaborate in this study. Both the 'organization structure' and 'management processes' aspects of organizational design will be further introduced in the next two subsections.

\subsection{Global sourcing organization structure}

Research on the aspects of organization structure in the global sourcing setting has mainly focused on the buyer's global sourcing organization structure. Organization structure is typically characterized by the dimension of centralization, identifying two basic structures of either centralized and decentralized organization (Arnold 1999; Faes et al. 2000; Giunipero and Monczka 1997; Johnson and Leenders 2001; Narasimhan and Carter 1990; Schneider and Wallenburg 2013).As global sourcing develops, organizations tend to move towards more centralized structures to achieve various synergy benefits (Karjalainen 2011). From the supplier's perspective, a centralized structure for global sourcing implies that there is a single interface towards the supplier. Recent trends have tended towards hybrid organization structures (Procurement Strategy Council 2013), combining aspects of centralization and decentralization (Johnson and Leenders 2001). In these hybrid structures, for example, the firm-level office maintains responsibility for the negotiation of longer-term contracts, while local units issue orders against these contracts (Trautmann et al. 2009a). Hybrid structures are especially suitable to capture benefits in terms of economies of scale, economies of processes, and economies of learning, while simultaneously retaining some degree of decentralization (Trautmann et al. 2009a). One of the key challenges in hybrid global sourcing structures is to decide what to centralize and what to decentralize (Matthyssens and Faes 1997). From the supplier perspective, the buyer's hybrid sourcing organization structure makes management of the BSR especially challenging; the supplier is required to manage the customer interface globally, while simultaneously providing variations at the local level.

In addition, research has identified categories (homogenous sets of products and services purchased from a common supply market and with similar product and spend characteristics) (Ates et al. 2017; Luzzini et al. 2012, 2014; Trautmann et al. 2009a, 2009b), geography (Giunipero and 
Monczka 1997), and business units (Narasimhan and Carter 1990) as the basis of global sourcing organization structure. Recently, Bals and Turkulainen (2017) discussed how the global sourcing organization structure supports outsourcing parts of Purchasing and Supply Management (PSM), while also developing an understanding of the fourth structural alternative of activity. Taken together, structural alternatives can be summarized as decisions along the dimensions of category, business unit/customer, geography, and activity, together with the decision on the degree of centralization (Bals et al. 2018). On the supplier side, research reports that the supplier organization structures are moving from being product- or geography-focused, towards more customercentric (Homburg et al. 2000; Toulan et al. 2006) due to the challenges they create for the management of the customer relationship (Guesalaga et al. 2018).

\subsection{Management processes at the buyer-supplier interface}

Processes, as the second aspect of organizational design, refer to the integration of the organizational interfaces (Lawrence and Lorsch 1967). Similarly, successful management of the BSRs requires integration of the interface (Ambrose et al. 2008; Kaipia and Turkulainen 2017; Revilla and Knoppen 2015; Terpend et al. 2008; Turkulainen et al. 2017). Integration refers to "the process of achieving unity of effort among the various subsystems in the accomplishment of the organization's task" (Lawrence and Lorsch 1967, p. 4).

Management of the buyer-supplier interface has gained considerable attention in the last couple of decades (Ambrose et al. 2008, 2010; Araujo et al. 1998; Cousins et al. 2006, 2008; Das et al. 2006; Gadde and Snehota 2000; Kaipia and Turkulainen 2017; Kulangara et al. 2016). In particular, there is an increasing trend towards closer BSRs, partnerships, and relational approaches (Araujo et al. 1998; Cousins and Menguc 2006; Gadde and Snehota 2000; Lahdenperä 2012; Quintens et al. 2006; Revilla and Knoppen 2015). Research, for example, suggests that not all BSRs are managed in the same way (Cousins et al. 2006; Kraljic 1983; Vesalainen and Kohtamaki 2015). The underlying idea is that developing relationships is resource-intensive and can be justified only if the benefits are greater than the costs (Kaipia and Turkulainen 2017). In one of the foundational works, Kraljic (1983) suggests that management of the BSR depends on the impact and supply risk of what is purchased.

Integration can be divided into coordination and cooperation (Gulati et al. 2005; Yan and Dooley 2013). The organizational boundary implies two differentiated organizations in terms of, for example, their structure and goals (Lawrence and Lorsch 1967). While the level of differentiation can be high even within the same organization (Lawrence and Lorsch 1967), it is likely higher between firms (Yan and Dooley
2013). Higher levels of differentiation increase the challenge of integration (Lawrence and Lorsch 1967; Turkulainen and Ketokivi 2012), implying that significant managerial effort is needed for the processes of integration.

Coordination refers to 'alignment of actions' and flows of information (Galbraith 1973; Nadler and Tushman 1997), so that the organizational units or organizations arrive at mutually beneficial outcomes (Faes et al. 2000; Pagell 2004; Turkulainen and Ketokivi 2012). Alignment of actions is needed due to a lack of shared knowledge (Bensaou and Venkatraman 1995; Gulati et al. 2005; Hwang et al. 2019; Yan and Dooley 2013), so coordination then facilitates processing of information and interaction across the organizational boundary (Cousins and Menguc 2006; Foerstl et al. 2013; Galbraith 1973; Nadler and Tushman 1997), thus building on the concept of bounded rationality (March and Simon 1958). In order to facilitate information flows between the organizations, the buyer and the supplier need to establish bi-directional, face-to-face, and multi-channel communication flows with each other to increase the richness of the information (Bensaou and Venkatraman 1995; Foerstl et al. 2013; Hwang et al. 2019). Coordination is essential to global sourcing as, by definition, global sourcing traditionally includes cross-functional coordination (Trent and Monczka 2003a, 2005). In the contemporary context, it potentially also requires external coordination with the suppliers (Wieland et al. 2020).

Second, cooperation as an aspect of integration refers to 'alignment of interests', which arise not just due to lack of information, but also various behavioral aspects (Gulati et al. 2005; Yan and Dooley 2013). Cooperation builds on the assumption that behavior is motivated by personal interests and benefits, and that subsequent uncooperative behavior tends to divert shared resources from serving joint needs and benefits to satisfying firms' interests (Gulati et al. 2005). Cooperation and alignment of interests can be facilitated by the development of common goals (Yan and Dooley 2013). If the goals are unified, for example, by developing and implementing incentives, individuals in each organization can be motivated to behave cooperatively, establish commitment, and pursue these common goals (Gulati et al. 2005). Cooperation and alignment of goals is critical in the global sourcing context, as global sourcing often tends to result in cross-functional and inter-organizational conflicts (Horn et al. 2014; Kotabe and Murray 2004; Stanczyk et al. 2015).

\subsection{Summary of research on organizational design aspects in the sourcing context}

We study how buyer-supplier interfaces are integrated for global sourcing, conceptualizing integration as coordination and cooperation. The following table (Table 1) provides a classification of exemplary research at the intersection of 
Table 1 Examples of research at the intersection of organizational design and sourcing*

\begin{tabular}{|c|c|c|}
\hline & Intra-organization focus & Inter-organizational focus on buyer-supplier interface \\
\hline $\begin{array}{l}\text { Generic } \\
\text { sourcing }\end{array}$ & $\begin{array}{l}\text { Centralization and decentralization } \\
\text { Rozemeijer et al. (2003) } \\
\text { Structural alternatives: categories, geography, BU, activities } \\
\text { Bals et al. (2018) } \\
\text { Coordination } \\
\text { Foerstl et al. (2013); Gonzalez-Zapatero et al. (2016); Pagell } \\
\quad \text { (2004); Turkulainen and Swink (2017) } \\
\text { Cooperation } \\
\text { Bals et al. (2009); Gonzalez-Zapatero et al. (2016); Pagell (2004) }\end{array}$ & $\begin{array}{l}\text { Coordination } \\
\text { Ambrose et al. (2008; 2010); Cavinato (1991); Kaipia and } \\
\text { Turkulainen (2017); Revilla and Knoppen (2015); Vanpoucke } \\
\text { et al. (2014); Haartman and Bengtsson (2015) } \\
\text { Cooperation } \\
\text { Ambrose et al. (2010); Chae et al. (2019); Caldwell et al. } \\
\text { (2009); Cousins et al. (2006, 2008); Revilla and Knoppen } \\
\text { (2015); Roehrich and Lewis (2014); Vanpoucke et al. (2014); } \\
\text { Vesalainen and Kohtamaki (2015); van de Vijver et al. } \\
\text { (2011); Villena et al. (2011); Yan and Dooley }(2013,2014)\end{array}$ \\
\hline $\begin{array}{l}\text { Global } \\
\text { sourcing }\end{array}$ & $\begin{array}{l}\text { Centralization and decentralization } \\
\text { Arnold (1999); Ates et al. (2017); Bals and Turkulainen (2017); } \\
\text { Cavinato (1991); Giunipero and Monczka (1997); Jia et al. (2014; } \\
\text { 2017); Karjalainen (2011); Luzzini et al. (2014); Narasimhan and } \\
\text { Carter (1990); Quintens et al. (2006); Trautmann et al. (2009b); } \\
\text { Trent and Monczka (2003b) } \\
\text { Structural alternatives: categories, geography, BU, activities } \\
\text { Ates et al. (2017); Bals and Turkulainen (2017); Jia et al. (2017); } \\
\text { Luzzini et al. (2014); Narasimhan and Carter (1990); Rozemeijer } \\
\text { et al. (2003); Trautmann et al. (2009b) } \\
\text { Coordination } \\
\text { Ates et al. (2017); Faes et al. (2000); Jia et al. (2017); Monczka } \\
\text { and Trent (1991); Narasimhan and Carter (1990); Schleper et al. } \\
\text { (2020); Trautmann et al. 2009a, 2009b; Trent and Monczka } \\
\text { (2003b); Trent and Monczka (2003a, 2005) } \\
\text { Cooperation } \\
\text { Horn et al. (2014); Kotabe and Murray (2004) }\end{array}$ & $\begin{array}{l}\text { Coordination } \\
\text { Bals and Turkulainen (2017); Wieland et al. (2020) } \\
\text { Cooperation } \\
\text { Horn et al. (2014) } \\
\text { The focus of our study: integration of the buyer-supplier inter- } \\
\text { face for global sourcing }\end{array}$ \\
\hline
\end{tabular}

*Please note that one study can be presented in several cells of the matrix depending on its focus

organizational design and sourcing. The intent is to summarize and further clarify the focus and positioning of this study. These examples are studies that have addressed organizational design aspects related to sourcing, both within the buying organization, as well as at the buyer-supplier interface. We have divided research into studies on global sourcing and generic sourcing (i.e. studies without a specific focus on global sourcing).

As Table 1 indicates, research on global sourcing has especially focused on the internal organizational design of the buying company while research on management of the buyer-supplier interface has addressed the generic sourcing setting. Our study links these two streams by focusing on developing understanding of how the buyer-supplier interface is integrated for global sourcing. As mentioned earlier, global sourcing poses a particularly challenging setting for both buyers and suppliers in terms of choosing the right business partner and managing the business relationship. Therefore, integration can be expected to be particularly pronounced and insights on potential structural alignments be more prominent than in the generic sourcing setting.

Figure 1 below represents the conceptual framework, graphically summarizing the organizational structural elements as well as the processes for integration of the buyer-supplier interface. The level of the analysis is at the organizational level, with the focus on the inter-organizational interface. Figure 1 summarizes the following: (1) understanding global sourcing organization structures requires analysis of the structural alternatives (dimensions of category, activity, geography, or business unit), as well as of the degree of centralization at both the global and local levels; (2) the link between organization structures and buyer-supplier interface and its integration; (3) integration as the processes of coordination and cooperation.

\section{Methodology}

\subsection{Research method}

In this study, we illustrate how the buyer-supplier interface is integrated for global sourcing, taking an organizational design view. For the purposes of this study, we collected empirical data following a single embedded unit case study design (Yin 2009). We selected this for four reasons. First, case studies facilitate the collection of rich data and the development of an understanding of complex organizational design matters (Dubois and Gibbert 2010; Piekkari et al. 


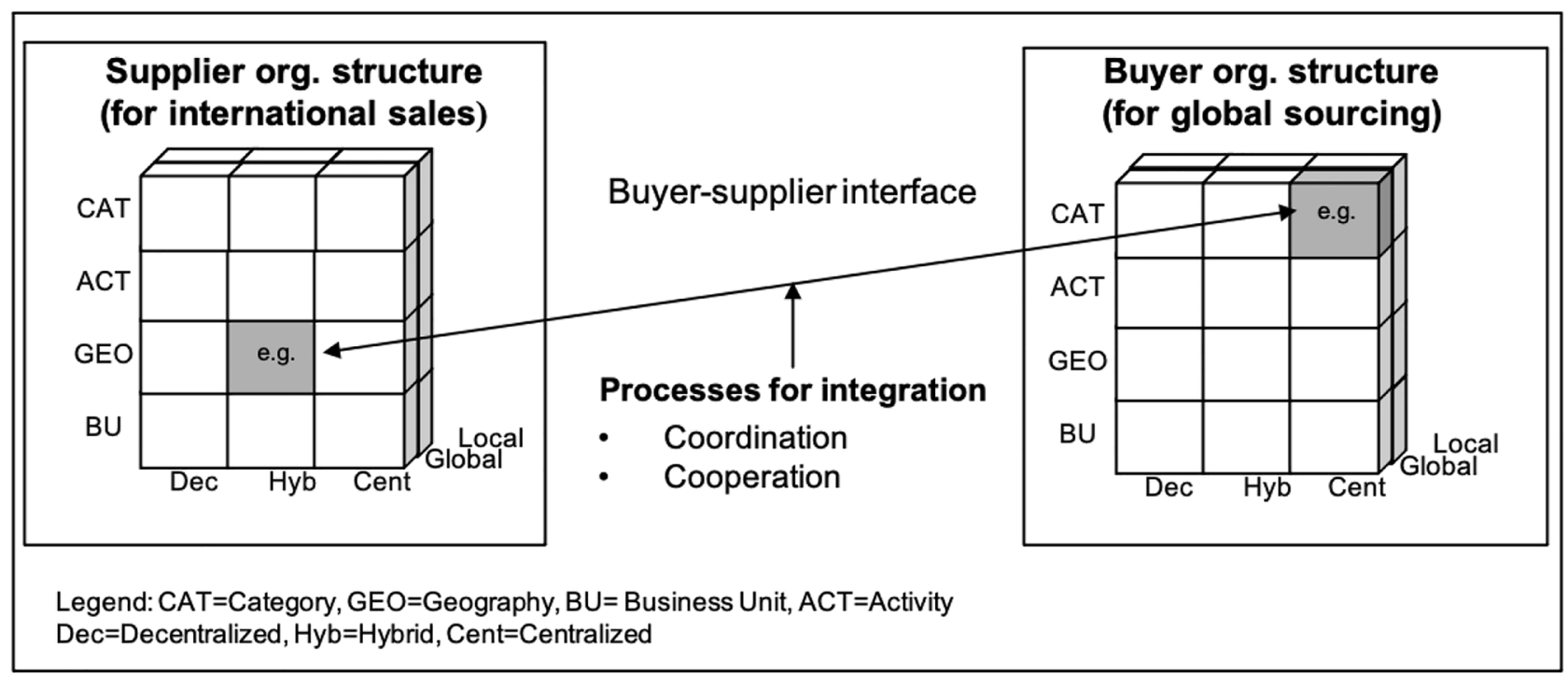

Fig. 1 Conceptual Framework: Global Sourcing and the Buyer-Supplier Interface - Organization Structure and Processes for Integration

2010). Second, case studies are well suited for research questions of "how" (Yin 2009), in line with our focus on how to integrate the buyer-supplier interface for global sourcing. Third, the case study method supports the aim of investigating a contemporary less-explored phenomenon in-depth and within its real-life context (Dubois and Gibbert 2010; Yin 2009). Finally, although a single case study is limited with respect to making generalizations, it fits the illustrative purpose of the empirical study (Ketokivi and Choi 2014). The unit of analysis is a relationship between a buyer engaged in global sourcing and its $1^{\text {st }}$ tier supplier. We consider a singleembedded case study suitable as it allows us to engage in analysis of multiple buyer-supplier relationships, while controlling for the organizational setting. Furthermore, a single case study is also appropriate as the purpose is illustration, not generalizability (Ketokivi and Choi 2014).

\subsection{Case selection and description}

For the purpose of developing understanding of integration of the buyer-supplier interface for global sourcing, we wanted to analyze a buyer organization that was sourcing globally and had adapted its global organization to facilitate that. The case company we selected is TechInd (pseudonym), which is a large provider of technical industrial product and service systems to, for example, the construction and shipbuilding industries. TechInd is headquartered in Germany and has over 40 subsidiaries in more than 30 countries. In 2018, it had around 25,000 employees and sales of over 1.5 billion Euros. Its core products are insulation, passive fire protection, surface protection, and interior outfitting. The operations of TechInd are project-based (Hayes and Wheelwright 1979) and relate to industrial plants, building construction, offshore platforms, and shipbuilding. We chose to focus the empirical part of the study in the projectbased operations context because while integration of the buyer-supplier interface is a major challenge in the ongoing operations context (Vanpoucke et al. 2014), the managerial challenge is even more significant in the context of projectbased operations. This is because project-based operations are typically characterized by lack of joint working experience and a pre-determined limited duration of operations and of the entire organizational relationship, as well as by aspects of uniqueness inherent in projects (Burke and Morley 2016; Lundin and Söderholm 1995). The management challenge is further increased by the fact that project-based industries, such as the industries in which TechInd operates, have traditionally been very local and are currently globalizing, allowing us to provide also direct practical value. We started research collaboration with TechInd already in 2016 as part of a larger study on organizational designs.

We selected TechInd for several reasons. First, TechInd had implemented a global sourcing strategy for several categories a number of years prior to our study. Second, we were given multi-year access to collect data to gain a detailed understanding of the organizational implications of global sourcing. Finally, we also got the opportunity to interview direct sales counterparts at six $1^{\text {st }}$ tier suppliers and receive the key account managers views and input on the management of the buyer-supplier interface. 


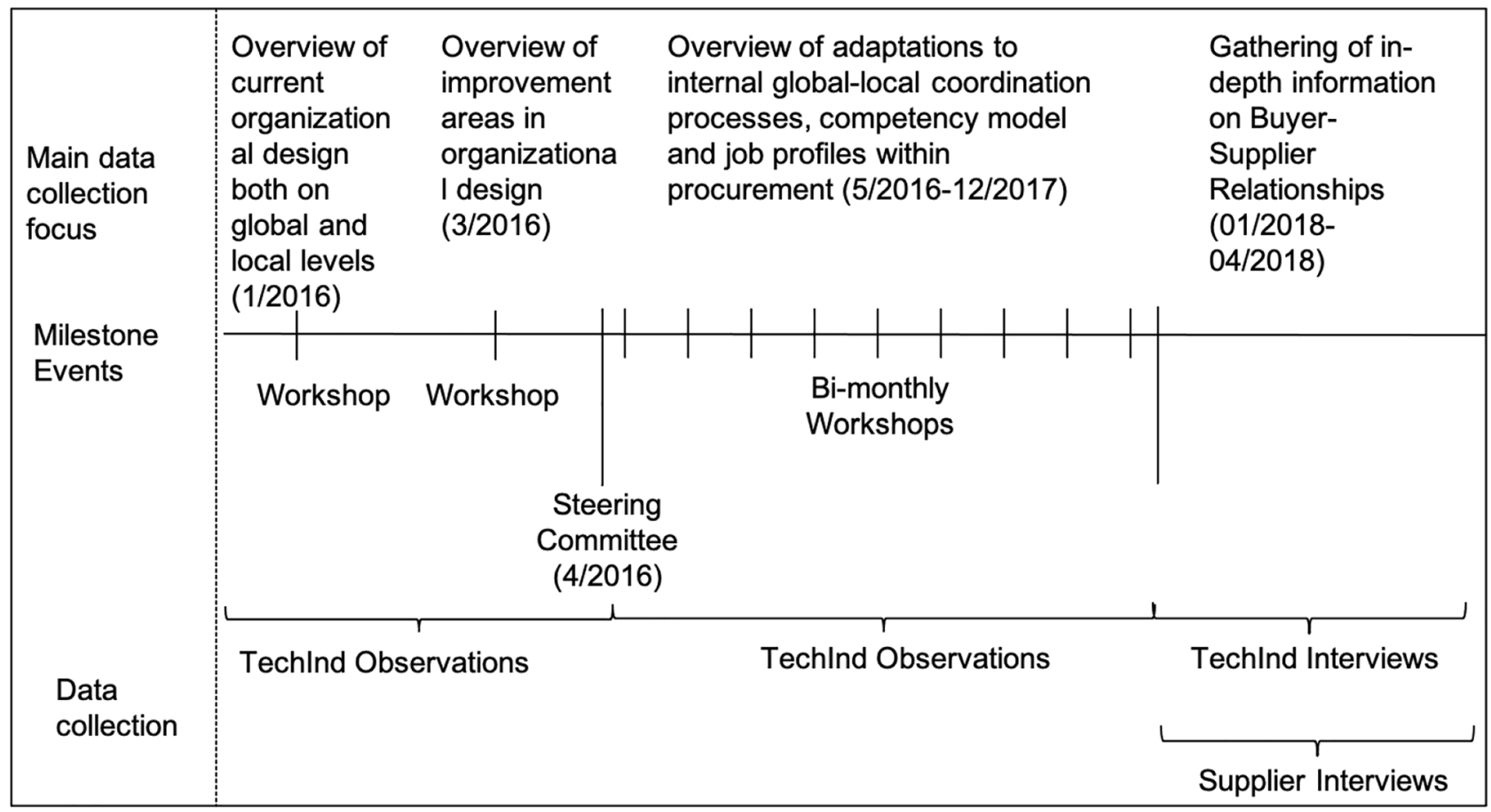

Fig. 2 Overview on data collection

\subsection{Data collection}

Data were mainly collected by interviews and systematic observations of managerial workshops and meetings over the period of study (2016-2018), as illustrated in Fig. 2. Based on the above conceptual framework developed for this paper, we developed an interview guide and conducted seven interviews at TechInd and six interviews with the suppliers in 2018. The interviewee demographics as well as some company background information for the suppliers are shown in Table 2. The interview guide is shown in Appendix A. It was used to facilitate discussion and as a general guide for the interviews. The interviews resulted in a total of 122 transcribed pages.

The systematic observations (2016-2018) were part of a larger study on buyer organizational designs and therefore particularly centered on understanding the buyer side. We were allowed to attend global sourcing organization design and implementation project workshops and gained access to all presentations, minutes and also took own observational notes. We also collected other material, such as charts and process descriptions. To combine both the observational and interview data allowed us to engage in data triangulation; for example, insights on organization structures were triangulated based on organization charts, workshop observations, and interview data.

Anonymity was ensured to the suppliers from the first contact onwards emphasizing that this is a research study that it is not directed by TechInd in any way. Informed consent was received from all interviewees. Only highly aggregated results (in terms of basic themes) were later reported back to both TechInd and the suppliers, as outlined to both parties before consenting. Moreover, the suppliers were encouraged to discuss their overall experiences related to organizational structures influencing the BSR. In the data analysis, the replies were carefully analyzed for both TechInd and the additional customer examples mentioned, and the display of results also differentiates those.

The interviewee selection and interview process had three major steps. First, we conducted an interview and had a discussion with the $\mathrm{CPO}$ about this research project, including purchasing organization, global sourcing, and the identified global sourcing categories. Second, we interviewed six global category managers about the BSRs and their integration. In these interviews, we also asked the interviewees to identify potential suppliers and their respective category for the study. We asked the category managers to position these categories on the Kraljic (1983) matrix because, as mentioned earlier, Kraljic suggests that management of the supplier relationship depends on the impact and supply risk of what is purchased. The choice of suppliers was made so that their category represents a large spend area, positioned as being high in importance (S1, S2 and S4 are classified as 'leverage' and S3, S5 and S6 are classified as 'critical'), as we expected that to be related to intensive interaction. Subsequently, we interviewed the supplier sales representatives. 
Table 2 Interviewee demographics

\begin{tabular}{|c|c|c|c|c|c|c|c|c|}
\hline Interviewee & Category & Position & $\begin{array}{l}\text { Tenure within } \\
\text { position (in } \\
\text { years) }\end{array}$ & $\begin{array}{l}\text { Practical } \\
\text { experience (in } \\
\text { years) }\end{array}$ & & & & \\
\hline \multicolumn{9}{|c|}{ Buyer (TechInd) representatives } \\
\hline B1 & $\begin{array}{l}\text { Insulation } \\
\text { materials }\end{array}$ & $\begin{array}{l}\text { Category } \\
\text { Manager } \\
\text { (global) }\end{array}$ & 5 & 30 & & & & \\
\hline B2 & $\begin{array}{l}\text { Scaffolding } \\
\text { and machin- } \\
\text { ery }\end{array}$ & $\begin{array}{l}\text { Category } \\
\text { Manager } \\
\text { (global) }\end{array}$ & 3,5 & 7,5 & & & & \\
\hline B3 & $\begin{array}{c}\text { Surface pro- } \\
\text { tection and } \\
\text { treatment }\end{array}$ & $\begin{array}{l}\text { Category } \\
\text { Manager } \\
\text { (global) }\end{array}$ & 5 & 9 & & & & \\
\hline B4 & Indirects (IT) & $\begin{array}{l}\text { Category } \\
\text { Manager } \\
\text { (global) }\end{array}$ & 3,5 & 10 & & & & \\
\hline B5 & N/A & $\begin{array}{l}\text { Head of } \\
\text { Corporate } \\
\text { Supply Man- } \\
\text { agement }\end{array}$ & 5 & 23 & & & & \\
\hline B6 & $\begin{array}{l}\text { Indirects } \\
\text { (Fleet; } \\
\text { C-Parts) }\end{array}$ & $\begin{array}{l}\text { Category } \\
\text { Manager } \\
\text { (global) }\end{array}$ & 1,5 & 8 & & & & \\
\hline B7 & Multiple & $\begin{array}{l}\text { Head of } \\
\text { Category } \\
\text { Management } \\
\text { (Germany) }\end{array}$ & 3 & 26 & & & & \\
\hline \multicolumn{3}{|c|}{ Supplier representatives } & & & $\begin{array}{l}\text { Duration of } \\
\text { (central) } \\
\text { buyer- } \\
\text { supplier } \\
\text { relationship } \\
\text { (in years) }\end{array}$ & $\begin{array}{l}\text { Supplier } \\
\text { number of } \\
\text { employees }\end{array}$ & $\begin{array}{l}\text { Supplier } \\
\text { turnover } \\
2018 \text { (in bn } \\
\text { EUR) }\end{array}$ & $\begin{array}{l}\text { Supplier inter- } \\
\text { national scope }\end{array}$ \\
\hline $\mathrm{S} 1$ & $\begin{array}{l}\text { Insulation } \\
\text { materials }\end{array}$ & $\begin{array}{l}\text { Commercial } \\
\text { Director }\end{array}$ & 3 & 20 & 12 & $>30,000$ & $>9$ & $\begin{array}{l}>250 \text { locations } \\
\text { in more than } \\
90 \text { countries }\end{array}$ \\
\hline $\mathrm{S} 2$ & $\begin{array}{l}\text { Scaffolding } \\
\text { and machin- } \\
\text { ery }\end{array}$ & $\begin{array}{l}\text { Business Unit } \\
\text { Manager }\end{array}$ & 10 & 24 & 10 & $>1,000$ & not published & $\begin{array}{l}5 \text { production } \\
\text { sites; sales } \\
\text { offices and } \\
\text { engineers } \\
\text { in }>15 \text { coun- } \\
\text { tries }\end{array}$ \\
\hline S3 & $\begin{array}{c}\text { Surface pro- } \\
\text { tection and } \\
\text { treatment }\end{array}$ & $\begin{array}{l}\text { Key Account } \\
\text { Manager }\end{array}$ & 6 & 26 & 2 & $>30,000$ & $>9$ & $>150$ countries \\
\hline $\mathrm{S} 4$ & $\begin{array}{c}\text { Surface pro- } \\
\text { tection and } \\
\text { treatment }\end{array}$ & $\begin{array}{l}\text { Global Sales } \\
\text { Director }\end{array}$ & 21 & 26 & 15 & $>10,000$ & $>19$ & $\begin{array}{l}>35 \text { produc- } \\
\text { tion facili- } \\
\text { ties in }>20 \\
\text { countries; } \\
\text { represented } \\
\text { in }>100 \\
\text { countries }\end{array}$ \\
\hline S5 & $\begin{array}{c}\text { Surface pro- } \\
\text { tection and } \\
\text { treatment }\end{array}$ & $\begin{array}{l}\text { Group Busi- } \\
\text { ness Devel- } \\
\text { opment } \\
\text { Manager }\end{array}$ & 5 & 20 & 5 & $>5,000$ & $>1$ & $>80$ countries \\
\hline
\end{tabular}


Table 2 (continued)

\begin{tabular}{|c|c|c|c|c|c|c|c|c|}
\hline Interviewee & Category & Position & $\begin{array}{l}\text { Tenure within } \\
\text { position (in } \\
\text { years) }\end{array}$ & $\begin{array}{l}\text { Practical } \\
\text { experience (in } \\
\text { years) }\end{array}$ & & & & \\
\hline$\overline{\text { S6 }}$ & $\begin{array}{l}\text { Surface pro- } \\
\text { tection and } \\
\text { treatment }\end{array}$ & $\begin{array}{l}\text { Area Manager } \\
\text { Nordics, } \\
\text { Protective } \\
\text { \& Marine } \\
\text { Coating }\end{array}$ & 4 & 30 & 1,5 & $>40,000$ & $>13$ & $\begin{array}{c}140 \text { produc- } \\
\text { tion facili- } \\
\text { ties in }>60 \\
\text { countries }\end{array}$ \\
\hline
\end{tabular}

During the whole research process, we engaged in several procedures to enhance validity and reliability. These are summarized in Table 3 below.

For the time period 2016-2017, the analysis particularly focused on gaining an in-depth understanding of the TechInd procurement organizational structure as well as management of the global-local dimensions. As can be seen from Fig. 2, there were amendments to the management approach during 2017, which could be captured in the observations and the related material. The analysis process for both these materials as well as the interview data collected subsequently, focused on tabularizing the data, and the results were then discussed among the authors, contrasting them with existing literature to interpret the findings. This was done in multiple iterations to challenge the interpretations. While the data gathered via the observational approach yielded a comprehensive view on the current status of the organizational design at TechInd, which was later triangulated with the interview data, and for example later summarized in Fig. 2 in this paper, the organization structures and processes related to management of the buyer-supplier interface (Fig. 1) served as the basis for developing our research design and guided for data collection and analysis of the interview data. Following the logic of theory elaboration, we engaged in constant comparisons between data and theory (Ketokivi and Choi 2014). The ex-ante coding tree is shown in Appendix B. The ex-ante nodes are directly related to the constructs presented in and described in the sub sections preceding Fig. 1. This ex-ante coding tree facilitated coding of the interview data, by allocating quotes to nodes (as illustrated in the supplementary material) and then subsequently aggregating and interpreting the findings towards propositions. In the latter, the researchers engaged in cross-checking their analyses to ensure consistency and agreement among researchers analyzing the data.

Table 3 Addressing validity and reliability criteria (see e.g., Dubois and Gibbert 2010; Yin 2009)

\begin{tabular}{|c|c|}
\hline Validity criterion & Means by which this was addressed in the case study \\
\hline $\begin{array}{l}\text { Objectivity: } \\
\text { Establishing reasonable freedom from unacknowledged researcher } \\
\text { biases and relative neutrality }\end{array}$ & $\begin{array}{l}\text { - Transparent, detailed, and explicit data collection and analysis by } \\
\text { developing and following a clear research design (details shown in } \\
\text { Fig. 2) }\end{array}$ \\
\hline $\begin{array}{l}\text { Reliability: } \\
\text { Demonstrating that the study process is consistent, reasonably stable } \\
\text { over time and across researchers and methods }\end{array}$ & $\begin{array}{l}\text { - Development of a case study database, facilitating data transparency } \\
\text { and transparency of the analysis } \\
\text { - Collection of data across a wide range of observations and carefully } \\
\text { selected respondents } \\
\text { - Development of an interview guide, shared among all interviewees } \\
\text { - Cross-checking of analysis to ensure consistency and agreement } \\
\text { among researchers analyzing the data }\end{array}$ \\
\hline $\begin{array}{l}\text { Construct validity: Establishing correct operational measures for the } \\
\text { study concepts }\end{array}$ & $\begin{array}{l}\text { - Use of a guiding theoretical framework as a basis to be elaborated by } \\
\text { the empirical study (Fig. 1) } \\
\text { - Multiple evidence and data sources through collection of all docu- } \\
\text { mentation prepared related to the organizational design (e.g., meeting } \\
\text { minutes, workshop summaries, own observational notes) } \\
\text { - Interview data summarized directly after each interview and sent to } \\
\text { interviewees for cross-checking }\end{array}$ \\
\hline $\begin{array}{l}\text { Internal validity: } \\
\text { Establishing causal relationships whereby certain conditions are } \\
\text { shown to lead to other conditions, as distinguished from spurious } \\
\text { relationships (of less concern in this study since causal inferences } \\
\text { were not made from the data) }\end{array}$ & $\begin{array}{l}\text { - Data collection in relation to the actual organizational aspects to } \\
\text { avoid recall bias and enhance data accuracy } \\
\text { - Both primary and archival data were analyzed to enable triangulation } \\
\text { - Information and data accuracy were improved by motivated inter- } \\
\text { viewees who were willing to participate in the study }\end{array}$ \\
\hline $\begin{array}{l}\text { External validity: } \\
\text { Establishing a domain in which the study's findings can be generalized }\end{array}$ & $\begin{array}{l}\text { - Clear description of case study company situation and context } \\
\text { - Detailed descriptions of specific contextual considerations of case } \\
\text { company studied }\end{array}$ \\
\hline
\end{tabular}




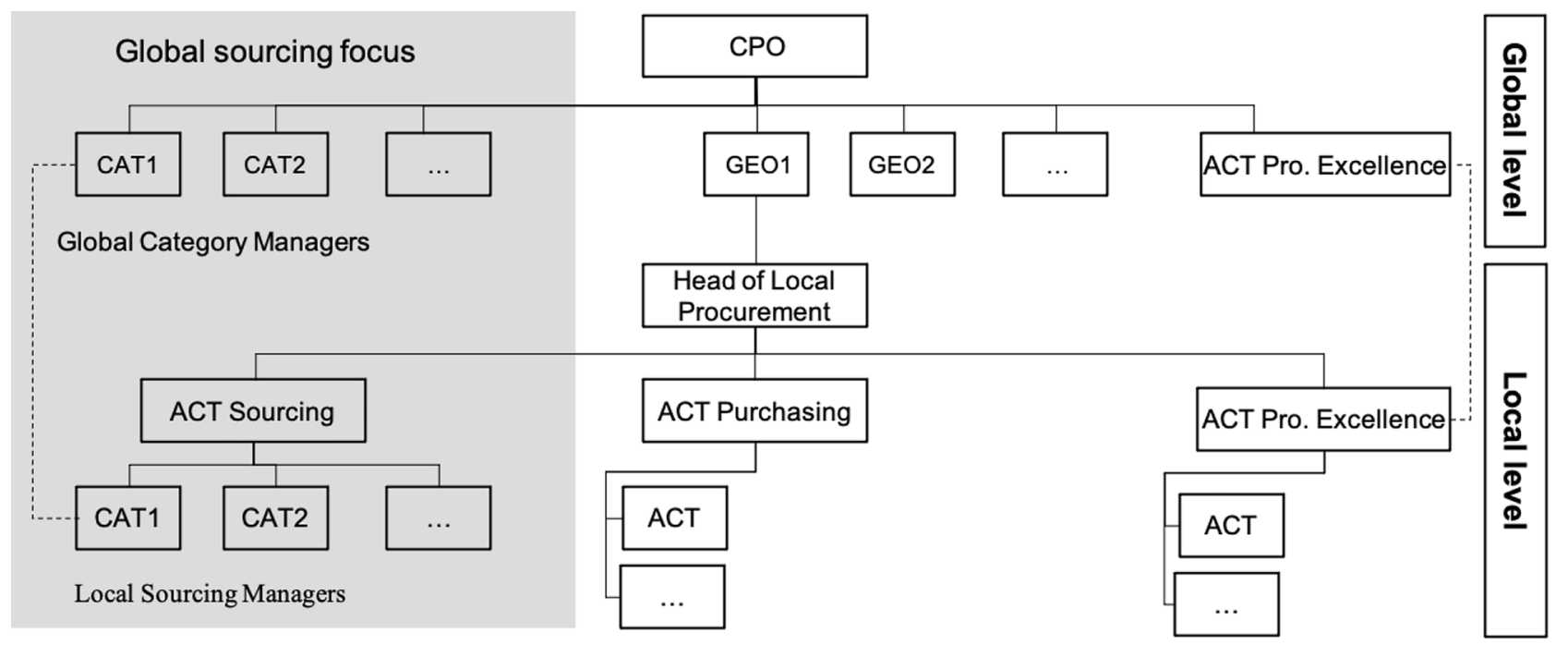

Legend: $\mathrm{CAT}=$ Category, $\mathrm{GEO}=$ Geography, $\mathrm{ACT}=$ Activity

Fig. 3 Global sourcing organization of TechInd, adapted from company materials

\section{Empirical analysis}

To illustrate how buyer-supplier interface is integrated for global sourcing, we analyzed the organization structures on both sides, as well as the processes for managing the BSR in line with the conceptual framework (Fig. 1).

\subsection{Organization structures}

We first present the procurement organization structure of TechInd, including global sourcing, and then the supplier sales organization structures (for details, please see Appen$\operatorname{dix}$ C).

\subsubsection{Buyer global sourcing organization structure}

The area shaded in grey in Fig. 3 highlights how global sourcing is organized at TechInd. On the global level, the organization is split between category managers ('CAT', reporting directly to the $\mathrm{CPO}$ ) and a procurement excellence department ('ACT', reporting directly to the CPO). On the local level, the country-based buying teams are organized into three process clusters: strategic sourcing, transactional purchasing, and the local process excellence department (i.e. performance management). ${ }^{2}$

Global sourcing at the company headquarters is organized mainly by category and carried out by global category

\footnotetext{
2 The purpose of this study is to illustrate a design and by no means to suggest that the organization structure at TechInd is ideal and should be followed by other firms.
}

managers. At the country level, there are local sourcing organizations based on the dimensions of activity and category. The global category managers are connected to the local country sourcing managers for each (major) global sourcing category with a dotted reporting line, facilitating alignment of actions and interests with the local sourcing counterparts for the respective category. Thus, the global category managers are the ones performing global sourcing activities and liaising with the local sourcing managers and other cross-functional stakeholders, as well as the management.

While the dotted reporting line between local sourcing managers and the global category managers facilitates their alignment of actions and interests throughout the categories, the local sourcing teams are represented by a geography in the overall procurement management team to further connect the country-based procurement organizations to the global level. This implies that the CPO would meet with the procurement heads of the three core countries, namely Germany, France, and the UK, on a quarterly basis during a management offsite event to jointly define priorities, targets, and development projects for both global and local procurement. This also facilitates alignment around global initiatives. The joint management team, consisting of the CPO and the country procurement heads, has become a forum for the global category managers to present proposals for global initiatives, as well as to ensure early buy-ins from the country procurement organizations for local stakeholder alignment, both in terms of internal stakeholders (e.g., local project managers) and external stakeholders (e.g., local suppliers). 


\subsubsection{Supplier sales organization structure}

The supplier sales organizations are predominantly organized by geography referring to a country-based or regional organization structure, with decision making responsibility mainly at the country or regional level. This decentralized structure is combined with key account managers (KAM), thereby creating a hybrid structure. So, for example, buyer 2 (B2) described the structural orientation of supplier 2 (S2) like this: "[Before nominating the global KAM] the maximum what they had was regional structure. So, they had a regional manager. Then then...our key account manager... he was the regional manager for Latin-America. And they have some regional manager for Asia Pacific [...].". And the Group Business Development Manager from supplier 5 (S5) explained: "On the sales side it is based on geography. So, meaning that every country or region has its own commercial team and setup." In addition to the geography dimension, S3 and S6 have a slightly more elaborated structure with a business unit (BU)/customer dimension, complementing decentralization of decision making by geography (for full details, please see Appendix C).

\subsection{Integration of the buyer-supplier interface for global sourcing}

As the second aspect of organizational design, we analyzed integration of the BSRs in light of the conceptual framework (Fig. 1), i.e. the processes of coordination (alignment of actions) and cooperation (alignment of interests). A summary of illustrative quotes is presented in Appendix D. In addition to the analysis of how the buyer-supplier interfaces are integrated, we have also included quotes describing what the interviewees described as hindering management of the interface.

The findings illustrate that the three organizational dimensions of the degree of centralization and structural alternatives, at both global and local levels, facilitate understanding of the global sourcing organization structure. TechInd's categorybased and activity-based hybrid organization structure makes the buyer-supplier interface fairly simple and clear: the suppliers have one point of contact globally, instead of multiple contacts in each country, providing a consolidated view on volume and requirements. This was associated with expectations regarding aggregated pricing for frame agreements and would be different if the buyer had a geography-based structure, for example, thereby implying that the supplier had to separately manage each country. For example, the Key Account Manager from supplier 3 (S3) describes this as follows: "Well, the relationship is now [managed] centrally. So, I'm running the frame agreements we have done. And yeah, that's only on the central level."

\subsubsection{Coordination: Alignment of actions}

Our analysis points out that despite being a hybrid, suppliers perceived the TechInd organization structure as decentralized in some instances. The suppliers related this to the lack of empowerment of the global category managers; in particular, instances in which decisions made by the global category managers at headquarters are not effectively communicated to and/or supported by the local sourcing managers. As the Area Manager of Nordics, Protective and Marine Coating from supplier 6 (S6) explained: The empowerment is maybe not to deliver where they really want it to be... So, for that matter we sometimes sit and talk about the possibility to work together more globally. And we are able to handle that. [...]. But I mean it seems like there are some challenges on [TechInd'] side on making sure that the procurement manager [...has] the empowerment in their organization to do this."

In instances where empowerment and actually living the implemented category-oriented global sourcing structure works, management of the buyer-supplier interface is easier and more straightforward. As the Area Manager of Nordics, Protective and Marine Coating from S6 explained in relation to a different client: "I mean the ones that I know the best is a company like [global container logistics company] where we are coordinating everything [...] from this office here. And also, where there is clearly a communicated empowerment in their organization that when we talk to their procurement people then they also have the power to take decisions across their organization irrespective of where it is in the world. And there you actually have a...then you actually get these synergies also a benefit for both for our parties. Because when you have a central point of contact and that we have seen working pretty well to be quite honest." This indicates that the structure is associated with the ability to achieve coordination both internally and externally. Moreover, our analysis points out that suppliers consider that a high level of centralization, together with internal coordination in the buyer organization facilitates management of the interface. At the same time, it makes management of that relationship more important because if that one contact decides to buy from another, all business would be lost at once. As the Group Business Development Manager from S5 explained: "From a higher level point of view [to have one central contact] is very convenient because I have one contact and he decides. But commercially it also makes me very vulnerable. I mean if something goes wrong in the relationship or whatsoever and this person decides to go to competition you lose all the business globally. Yeah, so it is positive but also involves a very high risk when the relationship goes wrong. If you have one very dominant central organized purchase department for example." 
Our analysis further indicates that geography-based, decentralized supplier sales organization structures pose challenges for the management of the buyer-supplier interface. This is because the buyer has a very different type of structure, implying that while the buyer has a single point of contact (SPOC) towards the supplier in each category, the suppliers tend to have multiple representatives for each category. This creates challenges in terms of information processing, for example, which was addressed by appointing key account managers (KAM). As buyer 1 (B1) accounted for S1: "[At the beginning around 2014 it was about] I'm coming down to your country, negotiate with you and flying out and have some kind of global agreements, but only one or two because most of the suppliers didn't want to work with us on a global perspective. Because they are set-up also very regional. So, if we are looking into the [new] procurement organization on how it works then we have these countries where it is feasible to work on that because they are big enough for having the split in the [activity] pillars."

Moreover, our analysis indicates that the decentralized geography-based supplier sales organization structure tried both to compensate decentralization and to achieve the benefits provided by a hybrid design (i.e. simultaneous management of global and local aspects) with KAMs. How the Commercial Director from S1 explained: "Well, we have several KAMs and they are doing the business with regional key accounts. For example, in the part of southern Germany, in the middle of Germany and in northern Germany. So, they are doing business together with the regional key accounts. Of course, we also have key accounts which are active Germany wide. And in that case the key account manager who has the headquarter in his area, he's responsible for that customer for the whole German business. That means that everyone has the same responsibility, the same structure regarding the area and number of customers. But they also have a very close link and information because everybody is involving the German business. And it's the same structure in other countries. If something is going abroad if we have for example contracting companies like [TechInd] or others who have a national business and also, international business everything which is international is on my desk. I'm involved. And because I'm leading the sales organizations I'm also involved in the local decisions." Or how the Area Manager of Nordics, Protective and Marine Coating from S6 described it: "There you need to take the next step in key account management and make a global or regional, but preferably global depending on the company of the customers of course. And then you have a global key account structure to manage that as I see it. But we have challenges in doing that as well because we are very geographically, and area based depending on our organizational structure. So [we face] exactly the same challenges just from the sales rather than a purchasing perspective that we have."
KAMs, as the central interface (SPOC) for the buyer in an otherwise decentralized sales organization, pose direct advantages; KAMs essentially represent a means to achieve coordination by simplifying the communication infrastructure between the two organizations.

\subsubsection{Cooperation (alignment of interests)}

Our analysis further points out the role of incentives in the management of the buyer-supplier interface, in particular, linking to cooperation and alignment of interests on the supplier side. For example, B1 explained it like this: "[...] again it is about the incentives, right? [...] and he said yeah, but we have some trouble [...]. And I said [is it] because [of] who is getting the provision for that? He said 'yes, of course, because I'm doing all the work and my colleague will benefit.' He's doing the business, right. And I'm saying 'yeah, that's true. But that's not my problem.' [...] they find a new way of incentivizing." And the Key Account Manager from S3 describes: "Yeah, well theory meets practice. Yeah, sometimes we have a central deal, but the country manager [...] has a project locally for that same company. And he can take it but at more or less a price which is arranged central. And he will walk away from it. Why? Because it's below his target or in terms of margins. So, he says well it's very nice globally if we can take this project at that price but then I lose...then I don't hit my target and I lose bonus. And I cannot go on holiday for instance. So, yeah you cannot pay me obviously because it's his own pocket, his own wallet which is hurting. But overall, it's not good for [S3's company] bottom line, of course."

Differing incentives seemed to especially hinder management of the interface; the analysis indicates a disconnect on the supplier side between the incentives of the geographybased organization structure (i.e. local sales managers have a certain sales target and bonus system) and the KAMs at the global level. For example, the local sales managers might want to drop a project, which is attractive from the company's perspective, but not from a local perspective, because of conflicting incentives (e.g., a country sales manager might lose his/her bonus if a sales offer becomes a 'global' contract).

\subsection{The project-based operations context}

As presented above, the findings illustrate that aligned structures between the buyer and the supplier organizations can facilitate management of the buyer-supplier interface, especially from the perspectives of alignment of actions and the related information processing. The findings further illustrate that the consequences of the lack of alignment of actions are aggravated by some of the underlying characteristics of the project-based operations context; for example, 
due to the nature of TechInd's projects, frame agreements cannot be enforced by a global category manager (e.g., in manufacturing operations, they would typically be implemented in a centralized ERP system and then remain relatively stable). Instead, as is typical for project-based operations, each and every project around the world that needs the negotiated material (e.g., blasting material) may or may not utilize the frame agreement. As the Key Account Manager from S3 mentions: "Yeah, sometimes we have a central deal, but the country manager will...has a project locally for that same company. And he can take it but at more or less a price which is arranged central." This creates a need for coordination and alignment of actions between the buyer and the supplier, particularly if the organization structures do not support it by themselves.

Another issue is that projects come up locally and are only temporal in nature, making it critical to align early on, if possible. As the Key Account Manager from S3 explained: "We have some clients that [jointly plan with us]. But unfortunately, they are not global. We have some suppliers in several countries [who] made a forecast with us. [...] They explained to us the projects they expect to have during the year. And then we can prepare ourselves. Unfortunately, with international companies this is very difficult because sometimes they don't know exactly the projects they are doing all around the world. So, sometimes you actually receive a phone call. I need for one week this material. So, with no planification this is difficult."

\section{Discussion}

\subsection{Conclusions on the research question and research implications}

Our research objective was to advance understanding of integration of the buyer-supplier interface for global sourcing by pursuing the research question: How to integrate the buyer-supplier interface for global sourcing? The study presents a conceptual framework on global sourcing organization design and integration of the buyer-supplier interface based on prior research (Giunipero and Monczka 1997; Gulati et al. 2005; Johnson and Leenders 2001; Narasimhan and Carter 1990; Yan and Dooley 2013) and empirically illustrates the framework. Our study provides further understanding of management of BSRs for global sourcing, especially in the project operations context as well as practical implications. In the following, we present 7 observations, discuss the findings as well as their implications to research.

Observation 1: Increased similarity of global sourcing and international sales organization structures (in terms of structural alternatives, degree of centraliza- tion, at both global and local levels) facilitates integration of the BSR.

Observation 2: Alignment of the global sourcing organization structure and the supplier sales organization structure facilitates coordination and alignment of actions at the buyer-supplier interface.

These observations can be linked to the law of requisite variety (Ashby 1956), which at the general level suggests that in order for the system to function well, the complexity of an organization should match the complexity of the environment and that matching organizational complexities on both sides of the interface facilitates functioning of the system. In the context of this study, we could interpret Ashby (1956) so that the organizational complexity on one side has implications for the organizational complexity on the other side. Similarly, but from the perspective of centralization only, research has proposed that management of BSRs is more successful if the supplier's customer-facing activities fit with the buyer's purchasing and supply activities (Toulan et al. 2006).

Furthermore, the information processing theory, suggesting that the buyer-supplier interface needs to be designed so that it facilitates the processing of inter-organizational information across the organizational interface (Galbraith 1973; Turkulainen et al. 2017), is also linked with these observations. On the other hand, information processing across organizational interfaces is hindered if there is asymmetry in the organizational setup; differences in organization structures across the interface imply that more managerial effort is needed in the processes of integration (Lawrence and Lorsch 1967; Turkulainen and Ketokivi 2012). This observation is in line with prior research suggesting that global sourcing increases the need for coordination between the buyer and suppler (Wieland et al. 2020) and that supplying firms are better able to serve their customers by having organization structures that mirror those of their customers (Guesalaga et al. 2018; Homburg et al. 2000; Toulan et al. 2006).

Observation 3: When the global sourcing organization structure is based on categories at the global level and activity at the local level, the BSR can be managed key account management (KAM) in the supplier organization to facilitate coordination and alignment of actions.

This observation is linked to prior research indicating that KAM as a practice aims at facilitating organizational alignment of actions (Storbacka 2012) and is designed to support fit between buyer and supplier organization structures (Homburg et al. 2000; Storbacka 2012; Toulan et al. 2006). Similarly, one of the reasons for why the activity-oriented design is suggested for facilitating coordination between the 
buyer and supplier in the case of outsourcing procurement is that the procurement providers are also often structured by activity (Bals and Turkulainen 2017). As such, KAM can facilitate information-processing between them and that organizational units or organizations arrive at mutually beneficial outcomes (Pagell 2004). This assignment of KAMs to manage the buyer-supplier interface is in line with research reporting that increasingly centralized approaches to purchasing are one of the reasons for introducing KAM to the supplier side (Capon and Senn 2010; Homburg et al. 2000; Swoboda et al. 2012). From a theoretical point of view, KAM thus facilitates coordination of activities, thereby enabling interaction and information processing across the organizational interface (Cousins and Menguc 2006; Foerstl et al. 2013).

\section{Observation 4: Hybrid global sourcing organization structure can be managed with aligned incentives at global and local levels to facilitate cooperation and alignment of interests in the supplier organization.}

Our findings illustrate that global sourcing has direct implications for supplier sales incentives; there is a need for alignment of incentives and/or shared incentives at both the global level and local/regional level (local sales managers). From a theoretical point of view, alignment of incentives facilitates cooperation and alignment of interests (Gulati et al. 2005; Yan and Dooley 2013). This is needed in order to manage the buyer-supplier interface in the context of global sourcing.

By providing a detailed illustration of a contemporary global sourcing organization structure, we complement existing research on global sourcing (Faes et al. 2000; Quintens et al. 2006; Giunipero and Monczka 1997; Jia et al. 2014; Johnson and Leenders 2001; Schneider and Wallenburg 2013), highlighting how hybrid organizations require aligned incentives at the global and local level, and how an organization structure based on category at the global and activity at the local level increases the need for KAM at the supplier. Thus, we also complement prior research, which has mainly focused on the structural implications of global sourcing for the buying company (Bals et al. 2018; Bals and Turkulainen 2017; Trautmann et al. 2009b) by considering also the sales perspective. In addition, we empirically illustrate inter-organizational implications of global sourcing, going beyond existing studies on the role of social capital (Horn et al. 2014) and in line with the increasing scope of global sourcing to cover both internal and external coordination and integration (Wieland et al. 2020).

By taking an organizational design perspective, we provide illustrations of integration of the buyer-supplier interface for global sourcing. This complements research on BSRs, which has traditionally focused, for example, on different BSR types and integration in the buyer-supplier interface in a generic sourcing context (Gadde and Snehota 2000; Kaipia and
Turkulainen 2017; Revilla and Knoppen 2015; Sheth and Sharma 1997; Vanpoucke et al. 2014). The case offered an illustration of how an increasingly complex global sourcing organization may require a more complex global sales organization from the supplier to facilitate management of the interface. This also gives support to the law of requisite variety (Ashby 1956); suppliers need to change their organizational complexity in order to react and adapt to the structure of the buyer, something prior research has only hinted at (Guesalaga et al. 2018; Homburg et al. 2000; Toulan et al. 2006). For example, while this notion of alignment between the buyer and supplier organization structures has been discussed in terms of the level of centralization (Toulan et al. 2006), our results imply that additional structural dimensions (i.e. the structural alternatives category, activity, geography and business unit) at the global and local level must be taken into account. Furthermore, the importance of the actual buyer organization structure for understanding the buyersupplier interface has recently been highlighted in relation to the activity-oriented design, which was found to facilitate the focal buyer's work with external procurement providers (Bals and Turkulainen 2017). Therefore, we also respond to the calls for research on the interdependence between buyersupplier organization structures (Bals and Turkulainen 2017; Guesalaga et al. 2018; Toulan et al. 2006). Moreover, we provide additional understanding on how coordination and alignment of actions, as well as cooperation and alignment of interests, are managed in the buyer-supplier interface (Gulati et al. 2005; Yan and Dooley 2013). Thereby the results illustrate how buyer-supplier interface is integrated for global sourcing as it is a particularly challenging setting for both buyers and suppliers.

The empirical findings also provide insight into global sourcing in the context of project-based operations.

Observation 5: The challenge of managing the buyersupplier interface from the perspective of coordination and alignment of actions is associated with the uniqueness and temporality characterized by the project-based operations context.

Observation 6: The challenge of managing the buyersupplier interface from the perspective of cooperation and alignment of interests is associated with the uniqueness and temporality characterized by the project-based operations context.

Observation 7: Managing the buyer-supplier interface can be managed with joint planning and early involvement between the buyer and the supplier to facilitate coordination and alignment of actions in the projectbased operations context.

These observations can be linked to the inherent uniqueness and temporality of the project-based operations context. Due to the projects being a vehicle to deliver outputs with at least some 
degree of uniqueness, and hence, being associated with at least partially changing needs for supplies and unique management processes, processing of information, coordination, and alignment of actions are typically needed on a project-by-project basis (Hayes and Wheelwright 1979; Ramasesh and Browning 2014). Even more, due to the temporality inherent in the project-based operations context, the organizational relationships are potentially changing and temporary in nature (Burke and Morley 2016; Lundin and Söderholm 1995; Turkulainen et al. 2013), implying that establishing information sharing and interaction, as well as aligning actions on a project-by-project basis, require significant emphasis.

The findings illustrate that incentives on the supplier sales side had a different scope than on the buyer side, which complicated the management of the buyer-supplier interface. This can be explained by the nature of the projectbased operations context. Due to some degree of uniqueness always inherent in the project-based operations context, more emphasis is needed to establish common goals and to facilitate cooperation on a project-by-project basis. Moreover, due to the temporality inherent in the project-based operations context, the organizational relationships are potentially changing and temporary in nature (Burke and Morley 2016; Lundin and Söderholm 1995; Turkulainen et al. 2013), implying that additional emphasis is needed to establish commitment and alignment of interests between the buyer and supplier on a project-by-project basis (Yan and Dooley 2013).

The findings further illustrate the importance of joint planning by the buyer and the KAMs for management of the buyer-supplier interface. Joint planning facilitates sharing of information and interaction (Haartman and Bengtsson 2015), and early involvement of KAMs in projects implies that they have immediate access to information when a new project is on the horizon (Lahdenperä 2012), thus facilitating information processing, coordination, and alignment of actions between the buyer and supplier as the project kicks off. The project-based operations setting makes the anticipation of exact business in terms of their nature, volumes, and delivery times more difficult than compared to more stable operations (Hayes and Wheelwright 1979), increasing the need for joint planning to manage the interface. This provides further insight into management of project-based operations (Artto and Turkulainen 2018; Ramasesh and Browning 2014; Turkulainen et al. 2013), and also provides valuable practical insight, as the number and importance of project-based operations has continued to grow significantly (Maylor and Turkulainen 2019).

\subsection{Managerial implications}

This study provides practical insights for practitioners. For buyers, it illustrates different ways to design the global sourcing organization, which has shown to be highly challenging (Schiele et al. 2011). The presented framework can help to clearly differentiate decisions on structural alternatives and the degree of centralization, at both the global and local levels, as well as the implications for the buyer-supplier interface. Before the structural dimensions were clarified at TechInd, the discussions always came back to whether people could be transferred to new locations (i.e. physical location was understood as synonymous to centralization/decentralization). The physical location, however, is not necessarily dictated by the structural alternative; people can be governed with different degrees of centralization regardless of their physical location. The supplier statements on empowerment underline that even if buyers change their organization structures toward one that provides one central point of contact for global sourcing in order to facilitate internal integration and subsequently external integration, it may still take time for the external parties to truly see 'one face to the supplier'. For such a transition, suppliers could be seen as allies. By informing them about the envisioned future modes of integration, the suppliers could work on fostering intra-organizational alignment on their own side accordingly (e.g., by aligning national sales offers towards global frame agreements). For the project-based operations context, the results particularly highlight the importance of joint planning and early involvement.

For suppliers, the study provides a framework to facilitate the analysis of buyers' global sourcing organizations. As the findings indicate, different designs may warrant different responses from the supplier (e.g., KAM in response to a category-based and activity-based hybrid sourcing organization). A single customer's organizational redesign in procurement may, of course, not necessarily lead to a fundamental redesign of the supplier sales organization, but nevertheless, awareness of the organizational (re)designs on the buyer side and their implications can help suppliers to master a tailored response (e.g. by nominating a KAM for that customer within an otherwise country-organized sales organization). By also being conscious about design options, the supplier is able to monitor if there is a trend among the most important customers in how they (re)structure their procurement organizations and consider how to structure their own sales organization.

\subsection{Limitations and suggestions for further research}

The empirical part of this study was based on the single embedded unit case study of TechInd and six of its $1^{\text {st }}$ tier suppliers. Although a single case study is well-suited for the illustrative purpose (Ketokivi and Choi 2014), it naturally poses limitations. These limitations, together with our findings, provide ideas for future research.

First, the various organizational design alternatives (Fig. 1) provide another interesting starting point for future 
research. Future research could build on this conceptualization to identify, for example, how contemporary companies engaging in global sourcing benefit from integration of the buyer-supplier interface. In practice, also studying which purchasing categories benefit most from such integration could be very enlightening.

Second, future research could further engage in studying the management of the buyer-supplier interface. This study offered illustrations of integration of the buyer-supplier interface for global sourcing, purposefully selecting certain kinds of suppliers based on the Kraljic (1983) matrix. Future research could address questions such as: How does the purchasing type further affect the BSR and its management (e.g. for strategic versus bottleneck categories)? How do different kinds of global sourcing organization structures (beyond the one illustrated here, e.g. Figure 3) affect management of the BSR? What are the implications of the buyer's global sourcing organization structure on the supplier side, in terms of, for example, the marketing and sales organizational design in different industries, and vice versa? Furthermore, research has indicated that organizational relationships have a fixed starting point and they evolve and develop over time (Ambrose et al. 2008; Vanpoucke et al. 2014) while depending on their history of interaction (van de Vijver et al. 2011). Future research could take a longitudinal perspective to see how the BSR and its management evolves over time. Research could also build on the contingency theory of organizations (Donaldson 2001), to assess global sourcing organizational structures and integration in BSRs in different operations contexts to identify potential contextual effects.

\section{Appendix A: Full interview protocol}

\section{Buyer interviews \\ Interviewee background}

1. What is your organizational position and role in this company?

2. What is your educational and professional background?

3. What is your tenure with the company and in this position?

\section{Current PSO structure and its evolution}

4. Where do you see your organization's Purchasing \& Supply Management (PSM):

a Main strengths?

b Main weaknesses?

5. Please describe the organization structure of your PSM department

a What has been the development path to the current structure? I.e. what changes have recently been made in the PSM structure (pre and post 2016). b What were the underlying reasons for the organizational changes?

6. How would you describe and classify your suppliers?

a How would you classify suppliers $\mathrm{X}, \mathrm{Y}, \mathrm{Z}$ in terms of dimensions of supplier risk and profit potential? (i.e. map examples on Kraljic's matrix)

7. How would you describe your overall approach to managing supplier relationships?

a Managing activities with suppliers and underlying reasons? What are the challenges? What works well? What would you do differently if you could? Could you give some examples?

b How has management of these supplier relationships changed over the past few years (pre and post 2016)? And why?

8. How would you describe your overall satisfaction with today's organizational set-up? And why?

\section{Supplier interviews Interviewee background}

1. What is your organizational position and role in this company?

2. What is your educational and professional background?

3. What is your tenure with the company and in this position?

Buyer relationships

4. What are you supplying to TechInd?

5. What is your company's history with this customer relationship?

6. How would you describe the relationship and how it is managed? Could you give some examples?

a How has the buyer relationship and its management changed over the past few years (pre and post 2016)? And why?

7. How would you describe your overall satisfaction with the buyer relationship management? And why?

8. Did you notice particular changes in how the relationship is managed (during the last years)?

9. Are you aware of any changes in the organizational structure of your customer?

10. If yes, how has this affected how you manage the customer relationship and why? Has a change in customer organization (in procurement) ever led to any organizational adaptations on your company's side. If yes, could you describe that? 


\section{Appendix B: Ex-ante coding tree (based on conceptual framework)}

\begin{tabular}{|c|c|c|c|}
\hline & $\begin{array}{l}\text { [Sub node } \\
\text { level 1] }\end{array}$ & $\begin{array}{l}\text { [Sub node } \\
\text { level 2] }\end{array}$ & Definition \\
\hline \multirow[t]{11}{*}{$\begin{array}{l}\text { Organizational } \\
\text { Structure }\end{array}$} & & & $\begin{array}{l}\text { Structural alter- } \\
\text { natives as deci- } \\
\text { sions on the } \\
\text { structure along } \\
\text { the dimensions } \\
\text { of category, } \\
\text { business unit/ } \\
\text { customer, } \\
\text { geography, } \\
\text { and activity, } \\
\text { together with } \\
\text { the decision } \\
\text { on aspects, } \\
\text { such as the } \\
\text { degree of cen- } \\
\text { tralization and } \\
\text { involvement } \\
\text { (Bals et al. } \\
\text { 2018) }\end{array}$ \\
\hline & $\begin{array}{l}\text { BUYER organ- } \\
\text { izational } \\
\text { structure }\end{array}$ & $\begin{array}{r}\text { Macro-level } \\
\text { geography }\end{array}$ & \\
\hline & & $\begin{array}{l}\text { Macro-level } \\
\text { business unit }\end{array}$ & \\
\hline & & $\begin{array}{l}\text { Macro-level } \\
\text { category }\end{array}$ & \\
\hline & & $\begin{array}{l}\text { Macro-level } \\
\text { activity }\end{array}$ & \\
\hline & & $\begin{array}{l}\text { Micro-level } \\
\text { (de)centrali- } \\
\text { zation }\end{array}$ & \\
\hline & $\begin{array}{l}\text { SUPPLIER } \\
\text { sales organi- } \\
\text { zational } \\
\text { structure }\end{array}$ & $\begin{array}{r}\text { Macro-level } \\
\text { geography }\end{array}$ & \\
\hline & & $\begin{array}{l}\text { Macro-level } \\
\text { business unit }\end{array}$ & \\
\hline & & $\begin{array}{c}\text { Macro-level } \\
\text { category }\end{array}$ & \\
\hline & & $\begin{array}{l}\text { Macro-level } \\
\text { activity }\end{array}$ & \\
\hline & & $\begin{array}{l}\text { Micro-level } \\
\text { (de)centrali- } \\
\text { zation }\end{array}$ & \\
\hline
\end{tabular}

\begin{tabular}{|c|c|c|c|}
\hline & $\begin{array}{l}\text { [Sub node } \\
\text { level 1] }\end{array}$ & $\begin{array}{l}\text { [Sub node } \\
\text { level 2] }\end{array}$ & Definition \\
\hline $\begin{array}{l}\text { Coordination } \\
\text { (alignment of } \\
\text { actions) }\end{array}$ & & & $\begin{array}{l}\text { Coordina- } \\
\text { tion refers to } \\
\text { "the degree } \\
\text { to which a } \\
\text { manufacturer } \\
\text { strategically } \\
\text { collaborates } \\
\text { with its supply } \\
\text { chain partners } \\
\text { and collabora- } \\
\text { tively manages } \\
\text { intra- and } \\
\text { inter-organiza- } \\
\text { tion processes" } \\
\text { (Flynn et al. } \\
\text { 2010) }\end{array}$ \\
\hline $\begin{array}{l}\text { Cooperation } \\
\text { (alignment of } \\
\text { interests) }\end{array}$ & & & $\begin{array}{l}\text { Cooperation } \\
\text { refers to } \\
\text { alignment } \\
\text { of interests, } \\
\text { which arise not } \\
\text { just due to lack } \\
\text { of information } \\
\text { but also due to } \\
\text { various behav- } \\
\text { ioral aspects } \\
\text { (Yan and } \\
\text { Dooley 2013). } \\
\text { This stream } \\
\text { of research } \\
\text { considers } \\
\text { that behavior } \\
\text { is motivated } \\
\text { by personal } \\
\text { interests and } \\
\text { benefits and } \\
\text { subsequent } \\
\text { uncooperative } \\
\text { behavior tends } \\
\text { to divert shared } \\
\text { resources from } \\
\text { serving joint } \\
\text { needs and ben- } \\
\text { efits to satisfy- } \\
\text { ing individual } \\
\text { firms' interests } \\
\text { (Gulati et al. } \\
\text { 2005) }\end{array}$ \\
\hline
\end{tabular}




\section{Appendix C: The buyer-supplier interfaces and their management}

\begin{tabular}{|c|c|c|c|}
\hline Supplier & $\begin{array}{l}\text { Supplier Organiza- } \\
\text { tion Structure }\end{array}$ & Information on the sales organization & Information on the interface and its management \\
\hline S1 & $\begin{array}{l}\text { Macro-level } \\
\text { dimension(s): } \\
\text { GEOGRAPHY } \\
\text { Micro-level: } \\
\text { hybrid }\end{array}$ & $\begin{array}{l}\text { "[...] it depends very much on the project and the application } \\
\text { of the project. In general, we can say we have got a very lean } \\
\text { structure in our company so that we have a direct impact on } \\
\text { product development and also on production. On the other } \\
\text { side if [TechInd] is involving their project managers or their } \\
\text { technical knowledge we can easily adapt their need to our } \\
\text { development and vice versa we can find a very quick and } \\
\text { easy solution which our competition and [TechInd's] compe- } \\
\text { tition cannot because their complexity in the organization is } \\
\text { much, much higher." (S1) } \\
\text { "Because most of the suppliers they are organized in regions or } \\
\text { even in countries." (B1) } \\
\text { "Yeah, I think [S1's company] for example. They only want } \\
\text { production site, but they have sales managers for the regions. } \\
\text { My first contact is the EMEA contact. But we are doing also } \\
\text { some business, or we are planning to do some business with } \\
\text { them for different regions in the world. And having some } \\
\text { RFQs." (B1) }\end{array}$ & $\begin{array}{l}\text { "[...] we are mostly talking about projects all over the world } \\
\text { and whenever something is coming up I immediately get a } \\
\text { request from [B1] or his colleagues to offer for the product." } \\
\text { (S1) } \\
\text { "So, we have two attempts working together with [TechInd]. } \\
\text { One is working together nationally. Like in Germany or in } \\
\text { other countries. And others are international projects where } \\
\text { we are working together with the headquarter of [TechInd]." } \\
\text { (S1) } \\
\text { "[At the beginning around } 2014 \text { it was about] I'm coming down } \\
\text { to your country, negotiate with you and flying out and have } \\
\text { some kind of global agreements, but only one or two because } \\
\text { most of the suppliers didn't want to work with us on a global } \\
\text { perspective. Because they are set-up also very regional. So, } \\
\text { if we are looking into the [new] procurement organization on } \\
\text { how it works then we have these countries where it is feasible } \\
\text { to work on that because they are big enough for having the } \\
\text { split in the [activity] pillars. [...] So, instead of having the } \\
\text { split heads we are trying to really have experts in the different } \\
\text { roles. Which is very, very interesting and good to see." (B1) } \\
\text { "And [S1's company is] willing to do it by service which is a } \\
\text { big part. We are not only focusing on price but like also the } \\
\text { price is always competitive [compared] to his competitors." } \\
\text { (B7) } \\
\text { "In my opinion we not have any given strategy we have to } \\
\text { represent. Of course, we have our company slogans and all } \\
\text { that stuff. And then the relationship to the supplier should } \\
\text { also have some kind of respect. Therefore, I'm the type of } \\
\text { guy who's really looking for partnership and like a long-term } \\
\text { relationship. [...] If you try to fool somebody of course he } \\
\text { will try to pay back sometimes. Or like if you really wear } \\
\text { somebody out. That's my opinion to the last drop. And when } \\
\text { he sees a chance to...if he has the chance for his turn then } \\
\text { he will ask for a higher price for example. And you have to } \\
\text { accept that because you have no choice." (B7) }\end{array}$ \\
\hline
\end{tabular}




\begin{tabular}{llll}
\hline Supplier & Supplier Organiza- & Information on the sales organization & Information on the interface and its management
\end{tabular}
tion Structure

S2 Macro-level dimension(s): GEOGRAPHY Micro-level: hybrid
"I am business unit manager for France, for Chile, Peru, Brazil and Spain where we have managing directors. [...] I am a key account manager for two companies: [company $\mathrm{X}$ ] and [TechInd], but globally. So, I receive some requests from Asia or from America or from Europe. Doesn't matter. I am the key account that...I collect information and I distribute in my organization but I am let's say the official messenger between [S2's company] or [company X] in that case." (S2) "[TechInd] was very active with [S2's company] in Latin America especially. And I was area manager of Latin America when they told us we want to have a key account manager, [our] Holding [...] decide[d] [I'm] the person because [I'm] the person that made [most] business in the world with [TechInd]. The same happened with [competitor $y$ of TechInd]. And the same happened with this person in Germany. That is the managing director of Germany. He is the one who has made more business with [competitor y of TechInd]. So, he was appointed as key account manager for this company to try to get more business in all the countries." (S2)

"And they are organized really all over the world. And we have other suppliers, competitors for them like [S2's company and] let's say none of the competitors has a really global footprint. They have region by regions, some are stronger some are weaker." (B2)

"[Before nominating the global KAM] the maximum what they had was regional structure. So, they had a regional manager. Then then...our key account manager...he was the regional manager for Latin-America. And they have some regional manager for Asia Pacific [...]." (B2)

"So, in protective coatings for instance, we also have key account manager power and energy which I did before. So, he will deal with [multinational energy technology and infrastructure company] and [multinational systems, services and equipment provider for the transport sector] and the likes like that." (S3)

"Yeah, well the actual agreements sit in the commercial departments in head office. But I'm pretty much the only one who knows how to deal, where to deal, what's the latest status. I mean if I would not be there from one day to the other okay they could read through the things and read through my emails but yeah, they have to start... large deal to start again." (S3)

"Yeah, you don't have the needs so, the personnel to cover every one of the key accounts with two persons. There is no budget for that. So, it is all slimmed down organizations and yeah, you have to deal with it alone. For handover and also within our company it's well... if you are lucky it should be almost a year with handover working side by side. But it's lucky if there is one month or one week even." (S3)

"Yeah, sometimes we have a central deal, but the country manager will...has a project locally for that same company. And he can take it but at more or less a price which is arranged central." (S3)
"Well, we have some relationships locally. Each entity has the relationship with the managing director of [TechInd]. I think normally every month we have a meeting with the managing director of each company. In my case I used to visit with all the [TechInd] companies in [Latin America] every quarter. [...] And I have a close relationship with the holding with the procurement person [B2]. And we used to be in contact at least two or three times by skype every month. We have a very frequent contact between us. Because of these frame agreements we are trying to implement." (S2)

"Yeah, [S2's company] was something where only local contacts were in the past. So, there was something in the past in South America already. Something in Spain. And I think it was my first supplier meeting year together with [B1]. We met [S2's company] and there we said clearly [...] we want a key account. If you want to build up something with us... a business, then you need to have a counterpart. They have organized this. They have done this. They have done their homework. It was their Latin-American manager. We had at that time the biggest business with [S2's company] there. And the most contact. And he spoke English fluently." (B2) "We are discussing some payments that we want to postpone. Or stretch a bit the due dates. And with [S2's company] we have already now ninety days. And I could find an agreement quite quick with them to stretch even the ninety days a bit longer." (B2)

"[To create competition by bringing S2's company in] helped against [competitor of S2]. And it will probably further help us to decrease the price level at the end. [...] We have monopolists. [Sometimes] in our industry the customer puts the supplier name into the specification" (B5)

"Well, the relationship is now centrally. So, I'm running the frame agreements we have done. And yeah, that's only on the central level. So, I'm normally not involved in particular projects or countries. That is still dealt with between local [TechInd] and local [S3's company]. So, only at the end of the year then yeah... for the repay which is in the part of the agreement we sit together. And of course, there are many contacts where we are starting up because it takes some time to start up such a...So, basically in the form of regional meetings where I will attend, where [B3] will attend from the headquarter sides and our local colleagues from both sides. And yeah, then we discuss how to improve business essentially." (S3)

"When it comes to passive fire protection [PFP] we have [S3]. Very successful. With placing a product [...]. We are using just within one specific product that has been designed in Norway [and with them we have] by far the highest spend." (B3) 


\begin{tabular}{|c|c|c|c|}
\hline Supplier & $\begin{array}{l}\text { Supplier Organiza- } \\
\text { tion Structure }\end{array}$ & Information on the sales organization & Information on the interface and its management \\
\hline S4 & $\begin{array}{l}\text { Macro-level } \\
\text { dimension(s): } \\
\text { GEOGRAPHY } \\
\text { Micro-level: } \\
\text { hybrid }\end{array}$ & $\begin{array}{l}\text { "So, we are...[S4's company] is a family company and we are } \\
\text { believing very much in the matrix organization. We are sup- } \\
\text { porting each other. [...] So, being part of that specification is } \\
\text { very much needed to be able to quote locally. Or in my posi- } \\
\text { tion. Because we haven't had this position before. So, then in } \\
\text { case of [multinational energy technology and infrastructure } \\
\text { company] has been building a power station in Vietnam it } \\
\text { was not possible to give our Vietnamese colleagues quotation } \\
\text { for this project in Vietnam. So therefore, we are... we know } \\
\text { that this is kind of a glocal business. It's always one third or } \\
\text { one fourth is above the water. You know if we are looking at } \\
\text { the iceberg the rest remains under the water. Of course, you } \\
\text { have to be in that specifications. And you have to be strong } \\
\text { locally as well. So, that's how we do glocal business." (S4) }\end{array}$ & $\begin{array}{l}\text { "[TechInd] is of course the contractor. And the contractor is } \\
\text { very often bound to fulfil their contract...Yeah, they have to } \\
\text { follow a specification. If [S4's company] is part of this speci- } \\
\text { fication, then [TechInd] is free to buy from [us]. [...] It's very } \\
\text { rarely that you are kind of single specified. And then it is... } \\
\text { of course we provide our products and services. Meaning } \\
\text { the technical sales support to make sure that these coatings } \\
\text { are applied correct. And [TechInd has] the choice [...]. Very } \\
\text { often [TechInd] is then selecting the cheapest vendor as it is } \\
\text { quite common in this industry." (S4) }\end{array}$ \\
\hline S5 & $\begin{array}{l}\text { Macro-level } \\
\text { dimension(s): } \\
\text { GEOGRAPHY } \\
\text { Micro-level: } \\
\text { hybrid }\end{array}$ & $\begin{array}{l}\text { "I would say for direct purchase it is organized geographically. } \\
\text { So, local. On a local level. But that's really related to the } \\
\text { concrete supply of products. More from a relationship point } \\
\text { of view then we take our headquarters meeting at [TechInd } \\
\text { headquarter location]." (S5) } \\
\text { "On the sales side it is based on geography. So, meaning that } \\
\text { every country or region has its own commercial team and } \\
\text { setup." (S5) } \\
\text { "I'm also commercially responsible for the group. Meaning } \\
\text { I report to our headquarters [...]. And we have a commer- } \\
\text { cially coordinating role globally. Meaning that I coordinate } \\
\text { international companies and projects together with my local } \\
\text { organization on a need-to-need basis." (S5) } \\
\text { "We have a team of [...] twenty people at the moment. We are } \\
\text { growing quite fast. The position itself is the same. We are } \\
\text { all global key account managers. But for example, myself I } \\
\text { come with the background oil and gas, at the moment I'm } \\
\text { moving more towards wind customers. I have also customers } \\
\text { dealing solely with engineering firms. Other colleagues } \\
\text { are dealing with floating units for example. So, there is a } \\
\text { segment difference. But the content of the positions is the } \\
\text { same." (S5) }\end{array}$ & $\begin{array}{l}\text { "We don't have a frame agreement in place. [...] this is quite } \\
\text { different for example Middle-East to South Europe etc. So, } \\
\text { we struggle a little bit to cover that in a frame agreement." } \\
\text { (S5) } \\
\text { "And [S5] I also find very interesting because coming out of } \\
\text { an area where they were just serving surface protection and } \\
\text { now want to go into PFP maybe they look from the bottom up } \\
\text { and say okay how can [TechInd] contribute. And I know they } \\
\text { had some technical discussions with our experts in a way that } \\
\text { they say 'okay, what's the crucial part in applying PFP"' [...] } \\
\text { And at least I think the guy from [S5] is really nice." (B3) }\end{array}$ \\
\hline S6 & $\begin{array}{l}\text { Macro-level } \\
\text { dimension(s): } \\
\text { GEOGRAPHY, } \\
\text { BUSINESS UNIT } \\
\text { Micro-level: } \\
\text { hybrid }\end{array}$ & $\begin{array}{l}\text { "[We are] a rather lean sales organization. We are part of a } \\
\text { European sales organization where we have the sales office } \\
\text { for the European marine and protective coatings sales } \\
\text { organization so we are basically in [country] or in my region } \\
\text { in each of the countries represented only with sales officers } \\
\text { and a lot of our services like financial, customer service are } \\
\text { in other parts of Europe. [...] So, we are quite functionally } \\
\text { organized as well." (S6) } \\
\text { "Well we have a split on sales areas. We have a marine sales } \\
\text { department and a protective coatings sales department." (S6) }\end{array}$ & $\begin{array}{l}\text { "Well, I think [...] on a technical level we [...] have some very } \\
\text { good discussions. Also, dialogues partly with the buyer and } \\
\text { partly with [TechInd's] technical organization. And I think } \\
\text { we have a good relationship with [...] the central buyers in } \\
\text { this area" (S6) } \\
\text { "When it comes to passive fire protection we have again [S6's } \\
\text { company]. Very successful. With placing a product." (B3) } \\
\text { "We are pushing hard. We often even come to a stage with } \\
\text { [S4's company] or [S6's company] that we might reach the } \\
\text { frame agreement. I'm not yet sure if it is really satisfying } \\
\text { then. I mean we go that way. And it's already a good step to } \\
\text { have an agreement." (B7) } \\
\text { "I just remember that we have closed a deal in Abu Dhabi with } \\
\text { [S6's company] where their offer has been outstanding low. } \\
\text { And I think they are offering it almost on cost level. That } \\
\text { means you have a difference in price towards competitors...to } \\
\text { the competition in a range of more than forty percent which } \\
\text { is ridiculously high. And at the same time, we were preparing } \\
\text { a quote for I think it was Kuwait. And there they have been } \\
\text { out. Because they gave a quote. They have been on the list of } \\
\text { suppliers to be addressed for a quote. And after the feedback } \\
\text { [...] that they have given at first they were far out of competi- } \\
\text { tion." (B3) }\end{array}$ \\
\hline
\end{tabular}

* mainly relevant dimension for sales counterparts when dealing with the global category managers. 


\section{Appendix D: Empirical analysis - Buyer-Supplier interface and its management}

\section{ORGANIZATIONAL STRUCTURE}

BUYER Organization structure

Macro-level geography + micro-level (de)centralization

Positive examples

"For example in a very large wind customer which is based in south Europe, the purchase department is very centralized organized. Meaning that every decision is made in Spain. No matter where the project is executed globally. From an overview point of view that is very convenient because I have one contact and he decides. But commercially it also makes me very vulnerable. I mean if something goes wrong in the relationship or whatsoever and this person decides to go to competition you lose all the business globally. Yeah, so it is positive but also involves a very high risk when the relationship goes wrong. If you have one very dominant central organized purchase department for example." (S5, general statement)

"[...] if a country organization from a big group is more independent yeah, you are more free to maneuver around in terms of price and also guarantees or technically coating-wise. And yeah, but it also makes it difficult on the other side. Then you can agree something in the head office. And you arrive somewhere. You are very friendly welcome with coffee etc. But they say we are not interested. So, yeah that's...And everything in between." (S3, general statement)

Negative examples

"[F]or our material the main buyer is [B7] speaking for purchasing in whole Germany. And we are in contact regarding that. However, decision seems to be made on the regional level. And it seems that these regional buyers are not linked to [B7]. That's sometimes the feeling we get because the decisions are made in different regions. So, one thing we discuss with [B7 is that although] we have good discussions, good however on the local area in the region the decision is made in a total different way. And that is difficult to understand if you do not have the internal view." (S1, specific statement in relation to TechInd)

"[The national business] is very fragmented and also quite difficult because there are different buyers in different regions and we do not see a clear buying strategy. The only thing what we see is focused on price, but we do not see what else are the key buying factors like quality, like logistics. And also, we can't see a purchasing strategy in Germany. Only thing is of course price which is a main driver in this business but there are also decisions made which are totally opposite in the north or in the south of Germany. So, it's not easy to get a clear picture and also information [...]." (S1, specific statement in relation to TechInd)

"I got told from the people working in the [TechInd] headquarter technically or commercial that they have hardly any influence on any local decision. This is something quite difficult because if it comes to areas like the middle east or what so ever then this...that's some other factors then logical sales argument and so on are playing into this you know. And then what we see we are losing quite sometimes some projects where factors coming into account which we cannot follow. And even the guys in the headquarter, [TechInd] headquarter cannot follow up. And sometimes this is a bit irritating I have to say." (S4, specific statement related to TechInd)

Macro-level category and geography + micro-level centralization

Positive examples

"Yeah, well. The funny thing is on paper they are normally quite well organized centrally. So, the big groups like [TechInd], [and a multinational energy company]. But in practice you will find that not every country is on the same page in every different amount of freedom. Within [TechInd] they are more or less...yeah, more directive as the German company. It's marching orders." (S3, specific statement in relation to TechInd)

Negative examples

"But yeah, with [multinational energy company] it's a bit different. Yes, we deal with the central procurements director, global category managers. But there are still countries, refineries where they will say well, it's nice that you agree something with our head office, but [...] we don't recognize that. Or we take it as an indication or friendly advice...But not as an instruction.” (S3, general statement)

"Yeah, well you have the risk of course. But on the other hand, then I see also with other accounts and my colleagues who have that situation where every [sales] decision is taken on a local level is that it's sometimes quite difficult to get all the knowledge to be on top of every situation, every opportunity. So, then you are very much depending on the effort of your local [sales] colleagues and your feedback." (S5, general statement) 


\section{ORGANIZATIONAL STRUCTURE}

SUPPLIER sales organization structure

Macro-level geography + micro-level decentralization + Key Account Role

\section{Positive examples}

"I mean if my customer is a key account that means I, no matter the question the key account has, regardless the type of products, I need to deal with the situation. Of course, we have departments and staff positions who are product specialists which I can rely on when I have a question or need assistance." (S5, general statement)

"So, the account management team will know what's going on [in R\&D]. So, we try to align that. And also, have a...As I see they have a global alignment of what I say if a company like [TechInd] have subsidiaries all around the world then we need to make sure that we have a coordinated approach in each of those countries. So, we have let's say account managers saying sales people, service people whatever is necessary in each of those areas. So, in that way align to their organization. For again, if there is at the customer side within let's say [TechInd]... if they have a structure where all decisions on coatings are taken by a centralized procurement organization and maybe in the category management team then of course we need to reflect that as well. So, we have a... sort of a global account management system meaning the negotiations and the discussions on that level. So, that way I think you get the most benefit for both parties by doing that." (S6, specific statement in relation to TechInd)

Negative examples

"And every time I said okay who will place the order? The local entity. Okay then it would be my colleague from that region. Same to him. Yeah, that may be. But I'm located here. And I negotiate with you. So, whatever I would like to do is I would like to talk to you. Whatever you are doing internally it doesn't matter for me. But I would like to have a SPOC [Single Point of Contact]. So, my SPOC will be you. So, and he went back within his organization which is a smaller organization [...and] he came back and said okay we find a solution internally [despite differing incentives]." (B1, specific statement in relation to TechInd)

"[Situation on the sales side is similar, as] at this moment the holdings of many companies want to centralize sales, want to centralize the contract. But it's different to find how to do it when you have subsidiaries all around the world. It's very similar in all the companies." (S2, general statement)

"Yeah, but also from our side there are sometimes resistances. There was...well we already have a good business with them locally why should we change something, or our pricing is very low. I don't have any space to pay a central rebate for a global turnover." (S3, general statement)

“Then he [the sales person] normally says, 'ah I mean pricing is a local issue. We shouldn't interfere. I think our guys can handle it.' So, where is the benefit for us? And that's actually something which we see very often." (B3)

"That is just as challenging for us on the sales side. That is challenging on the procurement side to make sure that this is aligned as well to make sure that let's say that [B3] needs to make sure that his purchasing organization is aligned with the contact he is making on a global level. We have the same challenges from our side to make sure that everybody are aligned in the way they do. So, I see we have exactly the same challenges. (S6, specific statement in relation to TechInd)

"But I mean as these organizations grow bigger and maybe also deal with global customers we need to be able to also show that you do the same service to for instance an oil major that is one of [TechInd] customers. We can service you around the world. Then they need to have that let's say alignment across their organization as well. And that is a sort of a...some of the challenges we see because then you actually...especially in that type of business because it's coming from a local orientation. Then it's more difficult and more challenging to understand that you have to think about something is... now decisions which are taken on the other side of the globe. And that is some of the challenges I think. And again, I see exactly the same challenges both now on procurement and on sales perspective. Because this is basically the same as I see it." (S6, specific statement related to TechInd)

"The local [sales] organization had their own profit and loss model. Which of course then leads to the fact that they have to make also a local decision regarding pricing. When it comes to the supply of products...I mean we have a lot of products, but we also have [core products which] are globally available no matter where we operate. And I must say that many of the products that [TechInd] is using are a part of the global list. So, those products are globally available. But then of course [there needs to be global] agree[ment] on pricing terms." (S5, specific statement in relation to TechInd) 


\section{ORGANIZATIONAL STRUCTURE}

\section{PROCESSES}

Coordination (alignment of actions)

Intra-organizational alignment

Positive examples

"Yeah. So, companies like [multinational energy technology and infrastructure company] they have in their headquarter... they have a corporate buyer and they have of course technical guys, corporate technical persons. And I'm talking to those guys and they are very close to their project management. But they know exactly what's going on and they know exactly the benefits why they choose a different solution. And this is for their benefit at the end of the day. And for their clients' benefit." (S4, general statement)

"I mean the ones that I know the best is a company like [global container logistics company] where we are coordinating everything [...] from this office here. And also, where there is clearly a communicated empowerment in their organization that when we talk to their procurement people then they also have the power to take decisions across their organization irrespective of where it is in the world. And there you actually have a...then you actually get these synergies also a benefit for both for our parties. Because when you have a central point of contact and that we have seen working pretty well to be quite honest." (S6, general statement)

Negative examples

"Absolutely. The other guys [i.e. the project managers] they are much, much more close to the project. And [TechInd] I feel they are far away at least in the headquarter. Very far away from the project and not knowing about the market situation, you know in this specific country where the project is going to be executed. They are too far away." (S4, specific statement related to TechInd)

"[...But] it seems to me that the empowerment of the global procurement manager or managers in [TechInd]... they are in [TechInd's] head office. The empowerment is maybe not to deliver where they really want it to be. If you know what I mean. So, for that matter we sometimes sit and talk about the possibility to work together more globally. And we are able to handle that. [...]. But I mean it seems like there are some challenges on [TechInd'] side on making sure that the procurement manager [...has] the empowerment in their organization to do this." (S6, specific statement related to TechInd)

"On regional level or in Germany I have to say it's difficult because you do not see the common mindset of all regional buyers. You can't really see a purchasing strategy. The only thing what we see when we look on the market if we compare experiences also listening to distributors. Only argument seems to be price." (S1, specific statement in relation to TechInd)

Inter-organizational alignment (Early Involvement and Commitment)

Positive examples

"Totally different is in the international business where we are talking directly with the project managers or with the category managers. There we get the information right from scratch when a project becomes obvious or known. We get involved about the timeline what kind of material specifications or needs [TechInd] or [TechInd's] customers have. And we can follow and support [TechInd] right from the beginning of there over to the customer until to the final end. That is a cooperation which I consider as very good. And we see especially over the last three years that we have continuously improved the business on both sides. For [TechInd] and as well for our company." (S1, specific statement in relation to TechInd)

"Yes. For strengths I just had... two weeks ago I came back with [multinational chemical company] with me and in Norway to visit our lab and research and development to apply coatings [...] Some weeks before [multinational energy technology and infrastructure company was] up there. And [TechInd] has been joining [our training program on paints]. So, we try really to build knowledge around that as well." (S4, general statement)

"We have some clients that [jointly plan with us]. But unfortunately, they are not global. We have some suppliers in several countries [who] made a forecast with us. [...] They explained to us the projects they expect to have during the year. And then we can prepare ourselves. Unfortunately, with international companies this is very difficult because sometimes they don't know exactly the projects they are doing all around the world. So, sometimes you actually receive a phone call. I need for one week this material. So, with no planification this is difficult." (S2, general statement)

"I have to say that normally the purchase organization of the international company are very professional. So, I don't think they need more tools to negotiate. What we always meet is what we talked about some minutes ago regarding some planification or forecast about what you are going to do. Because we are manufacturers." (S2, general statement)

Negative examples

"Yes, there is one point which really should considered more in general in our industry. It's category management because what I'm realizing is if I just look on the countries I'm responsible for I see that more than ninety percent of the category managers are just named category managers. However, they are just doing traditional purchasing jobs. And I was also experiencing contracting companies where the project managers where saying yes purchasing did a good job, but it did not get the right material. Because I would have needed a material which is a little bit more expensive which helps me with my installation. So, the branch is still too much focused on traditional purchasing and just only on price. And very often it seems that the price is the only driving factor and we see on the construction site that the workers have sometimes problems with the material because they are not involved in the buying process." (S1, general statement)

"I think it's quite similar the relationship in terms of communication. We try to have always a transparent and a clear communication. [...] So, it's difficult to match what the holding wants and what the operational companies want. At the same time, it's as well difficult to find agreements, global agreements because markets are different, prices are different. You have the transportation. And then it's not easy to find a global agreement. Because when you are talking about an agreement worldwide taxes are different. Export taxes are different. So, it's not difficult.. sorry, it's a little bit difficult but it's possible. [...] Our experience as well is that when we are trying to sign a frame agreement or a global agreement with some companies they want to have from us the better prices. They want to have from us the better conditions. They always reject to have any commitment with us. So, we ask for example we can sign an agreement with your company, but you have to guarantee to us [...] some millions of sales orders. And this is always reactive. So, they want to have very good prices, but any let's say any commitment from his side. So, sometimes these papers or these documents can be only... what paper because finally to sign but they don't have any obligation to buy or to make business with us." (S2, general statement) 


\section{ORGANIZATIONAL STRUCTURE}

Cooperation (alignment of interests)

Incentives

\section{Positive examples}

"[...] again it is about the incentives, right? [...] and he said yeah, but we have some trouble [...]. And I said [is it] because [of] who is getting the provision for that? He said 'yes, of course, because I'm doing all the work and my colleague will benefit.' He's doing the business, right. And I'm saying 'yeah, that's true. But that's not my problem.' [...] they find a new way of incentivizing." (B1, specific statement in relation to TechInd)

"I mean that depends a little bit on the exact product category. For some product categories are commoditized, some are more specialized. And the more specialized or the more let's say technical oriented product, you need a more let's say involvement of the technical departments and technical people from both sides. And I would say that the...my experience with the... not only [global container logistics company] but also others globally more organized companies. Then you need to have both levels involved. I need to have both technical and you need to have a procurement purchasing but also if need the supply chain etc. involved in these things from both parties. So, I think it's a team from both sides. As ultimately these depends on both sides on the complexity of the customer. Or the... on the accounts. I think that here you need to have all involved, and my experience depending on the level of cooperation. The more people you need to have involved in that. And you need to have a specialist in different areas. You can't only have one account manager dealing with everything. Then you overlook people. If you understand what I mean.” (S6, general statement)

Negative examples

"The sales people have quite a high share of the national business because their decision for the national key account and also in the area are affecting national business. For example, it can happen that a contractor in Munich is doing a project in Berlin area and vice versa. So, there is a high share regarding the whole German business. And on the other hand side, of course they are responsible for their local business. An it's more or less the same share. Of course, all the other effects are sales targets, margin targets and things like that." (S1, specific statement in relation to TechInd)

"Well, we have several key account managers and they are doing the business with regional key accounts. For example, in the part of southern Germany, in the middle of Germany and in northern Germany. So, they are doing business together with the regional key accounts. Of course, we also have key accounts which are active Germany wide. And in that case the key account manager who has the headquarter in his area, he's responsible for that customer for the whole German business. That means that everyone has the same responsibility, the same structure regarding the area and number of customers. But they also have a very close link and information because everybody is involving the German business. And it's the same structure in other countries. If something is going abroad if we have for example contracting companies like [TechInd] or others who have a national business and also, international business everything which is international is on my desk. I'm involved. And because I'm leading the sales organizations I'm also involved in the local decisions [...]. Because sometimes distributors are offering for a project. We are offering for a project. And customers or competitors from other countries are also offering on the same project. So, you have to clarify that you do not make competition within your own organization. And also, that you are aware of the full scope of the orders and the project at the moment." (S1, specific statement in relation to TechInd)

"Because most of the suppliers they are organized in regions or even in countries. And they are also responsible for their profits, margins, etc. So, they don't like that somebody above them...they get the targets, but they take...their headquarter is taking away one of the opportunities to work on that target. Because saying whatever you are doing with [TechInd] this is the price. We negotiate it. Or the discount or whatever. If this is the case, then we need to reduce my target. But this is...for me honestly it is like everywhere else in the world. Incentives. It's all the time the question. So, if you are changing a process or an organization you need to change your way of incentives to the people." (B1, specific statement in relation to TechInd)

"Yeah, well theory meets practice. Yeah, sometimes we have a central deal, but the country manager [...] has a project locally for that same company. And he can take it but at more or less a price which is arranged central. And he will walk away from it. Why? Because it's below his target or in terms of margins. So, he says well it's very nice globally if we can take this project at that price but then I lose...then I don't hit my target and I lose bonus. And I cannot go on holiday for instance. So, yeah you cannot pay me obviously because it's his own pocket, his own wallet which is hurting. But overall it's not good for [S3's company] bottom line, of course. So, in such cases sometimes we make a separate deal that a certain project is not counted for the results on that country. Profits or loss, you can't. But yeah, you have some resistance also in that setup." (S3, specific statement in relation to TechInd)

"And what you say about bonuses that's let's say spot on some of the challenges we have to deal with. And that is from...if you look at it from a traditionally geographically organized structure it's typically a challenge. There you need to take the next step in key account management and make a global or regional, but preferably global depending on the company of the customers of course. And then you have a global key account structure to manage that as I see it. But we have challenges in doing that as well because we are very geographically, and area based depending on our organizational structure. So [we face] exactly the same challenges just from the sales rather than a purchasing perspective that we have." (S6, specific statement in relation to TechInd)

Author contributions All authors contributed to the study conception and design. Material preparation, data collection and analysis were performed by Lydia Bals and Virpi Turkulainen. The first draft of the manuscript was written by Lydia Bals and Virpi Turkulainen and all authors commented on previous versions of the manuscript. All authors read and approved the final manuscript.

Funding Open Access funding enabled and organized by Projekt DEAL.

Data availability Data was collected by the authors.

\section{Declarations}

\section{Competing interests None.}

Open Access This article is licensed under a Creative Commons Attribution 4.0 International License, which permits use, sharing, adaptation, distribution and reproduction in any medium or format, as long as you give appropriate credit to the original author(s) and the source, provide a link to the Creative Commons licence, and indicate if changes were made. The images or other third party material in this article are 
included in the article's Creative Commons licence, unless indicated otherwise in a credit line to the material. If material is not included in the article's Creative Commons licence and your intended use is not permitted by statutory regulation or exceeds the permitted use, you will need to obtain permission directly from the copyright holder. To view a copy of this licence, visit http://creativecommons.org/licenses/by/4.0/.

\section{References}

Ambrose E, Marshall D, Fynes B, Lynch D (2008) Communication media selection in buyer-supplier relationships. Int J Oper Prod Manag 28:360-379

Ambrose E, Marshall D, Lynch D (2010) Buyer supplier perspectives on supply chain relationships. Int J Oper Prod Manag 30:1269-1290

Araujo L, Dubois A, Gadde LE (1998) Managing interfaces with suppliers. Ind Mark Manage 28:497-508

Arnold U (1999) Organization of Global Sourcing: Ways toward an optimal degree of centralization. Euro J Purchas Supp Manag 5:167-174

Artto K, Turkulainen V (2018) It takes two to tango: Product-organization interdependence in managing major projects. Int J Oper Prod Manag 38:1312-1339

Ashby WR (1956) Introduction to Cybernetics. Chapman \& Hall, London

Ates MA, van Raaij E, Wynstra F (2017) The impact of purchasing strategy-structure (mis)fit on purchasing cost and innovation performance. J Purch Supply Manag 24:68-82

Bals L, Turkulainen V (2017) Achieving efficiency and effectiveness in purchasing and supply management: organization design and outsourcing. J Purch Supply Manag 23:256-267

Bals L, Hartmann E, Ritter T (2009) Barriers of purchasing departments' involvement in marketing service procurement. Ind Mark Manage 38:892-902

Bals L, Laine J, Mugurusi G (2018) Evolving purchasing and supply organizations: a contingency model for structural alternatives. J Purch Supply Manag 24:41-58

Bensaou M, Venkatraman N (1995) Configurations of interorganizational relationships: A comparison between US and Japanese automakers. Manage Sci 41:1471-1492

Burke CM, Morley MJ (2016) On temporary organizations: A review, synthesis and research agenda. Human Relations 69:1235-1258

Burton RM, DeSanctis G, Obel B (2006) Organizational design - a stepby-step approach. Cambridge University Press, New York, NY

Caldwell N, Roehrich JK, Davies AC (2009) Procuring complex performance in construction: London Heathrow Terminal 5 and a Private Finance Initiative hospital. J Purch Supply Manag 15:178-186

Capon N, Senn C (2010) Global customer management programs: how to make them really work. Calif Manage Rev 52:32-55

Cavinato JL (1991) Evolving procurement organizations: logistics implications. J Bus Logist 13:27-45

Chae S, Lawson B, Kull TJ, Choi T (2019) To insource or outsource the sourcing? A behavioral investigation of the multi-tier sourcing decision. Int J Oper Prod Manag 39:385-405

Cousins PD, Menguc B (2006) The implications of socialization and integration in supply chain management. J Oper Manag 24:604-620

Cousins PD, Lawson B, Squire B (2006) An empirical taxonomy of purchasing functions. Int J Oper Prod Manag 26:775-794

Cousins PD, Lawson B, Squire B (2008) Performance measurement in strategic buyer-supplier relationships: The mediating role of socialization mechanisms. Int J Oper Prod Manag 28:238-258

Das AJ, Narasimhan R, Talluri S (2006) Supplier integration - finding an optimal configuration. J Oper Manag 24:563-582
Donaldson L (2001) The contingency theory of organizations. Sage, Thousand Oaks

Dubois A, Gibbert M (2010) From complexity to transparency: Managing the interplay between theory, method and empirical phenomena in IMM case studies. Ind Mark Manage 39:129-136

Faes W, Matthyssens P, Vandenbempt K (2000) The pursuit of global purchasing synergy. Ind Mark Manage 29:539-553

Flynn BB, Huo B, Zhao X (2010) The impact of supply chain integration on performance: A contingency and configuration approach. J Oper Manag 28:58-71

Foerstl K, Hartmann E, Wynstra F, Moser R (2013) Cross-functional integration and functional coordination in purchasing and supply management: Antecedents and effects on purchasing and firm performance. Int J Oper Prod Manag 33:689-721

Gadde LE, Snehota I (2000) Making the most of supplier relationships. Ind Mark Manage 29:305-316

Galbraith JR (1973) Designing complex organizations. addison-wesley, Reading, MA

Giunipero LC, Monczka RM (1997) Organizational approaches to managing international sourcing. Int J Phys Distrib Logist Manag 27:321-336

Gonzalez-Zapatero C, Gonzalez-Benito J, Lannelongue G (2016) Antecedents of functional integration during new product development: The purchasing-marketing link. Ind Mark Manage 52:47-59

Guesalaga R, Gabrielsson M, Rogers B, Ryals L, Cuevas JM (2018) Which resources and capabilities underpin strategic key account management? Ind Mark Manage 75:160-172

Gulati R, Lawrence PR, Puranam P (2005) Adaptation in vertical relationships: Beyond incentive conflict. Strateg Manag J 26:415-440

von Haartman R, Bengtsson L (2015) The impact of global purchasing and supplier integration on product innovation. Int $\mathrm{J}$ Oper Prod Manag 35:1295-1311

Hayes RH, Wheelwright SC (1979) Link manufacturing process and product life cycles. Harv Bus Rev 57:133-140

Homburg C, Workman JP Jr, Jensen O (2000) Fundamental changes in marketing organization: The movement toward a customerfocused organizational structure. J Acad Market Sci 28:459-478

Horn P, Scheffler P, Schiele H (2014) Internal integration as a pre-condition for external integration in global sourcing: a social capital perspective. Int J Prod Econ 153:54-65

Hwang S, Kim H, Hur D, Schoenherr T (2019) Interorganizational information processing and the contingency effects of buyerincurred uncertainty in a supplier's component development project. Int J Prod Econ 210:169-183

Jia F, Lamming R, Sartor M, Orzes G, Nassimbeni G (2014) Global purchasing strategy and international purchasing offices: Evidence from case studies. Int J Prod Econ 154:284-298

Jia F, Orzes G, Sartor M, Nassimbeni G (2017) Global sourcing strategy and structure: Toward and integrated conceptual framework. Int J Oper Prod Manag 37:840-864

Johnson PF, Leenders MR (2001) The supply organizational structure dilemma. J Supply Chain Manag 37:4-11

Kaipia R, Turkulainen V (2017) Managing integration in outsourcing relationships - the influence of cost and quality priorities. Ind Mark Manage 61:114-129

Karjalainen K (2011) Estimating the cost effects of purchasing centralization-Empirical evidence from framework agreements in the public sector. J Purch Supply Manag 17:87-97

Ketokivi M, Choi T (2014) The renaissance of case research as a scientific method. J Oper Manag 32:232-240

Kotabe M, Murray JY (2004) Global sourcing strategy and sustainable competitive advantage. Ind Mark Manage 33:7-14

Kraljic P (1983) Purchasing must become supply management. Havard Business Review 61:109-117 
Kulangara NP, Jackson SA, Prater E (2016) Examining the impact of socialization and information sharing and the mediating effect of trust on innovation capability. Int J Oper Prod Manag 36:1601-1624

Lahdenperä P (2012) Making sense of the multi-party contractual arrangements of project partnering, project alliancing and integrated project delivery. Constr Manag Econ 30:57-79

Lawrence PR, Lorsch JW (1967) Differentiation and integration in complex organizations. Adm Sci Q 12:1-47

Lundin RA, Söderholm A (1995) A theory of temporary organization. Scand J Manag 11:437-455

Luzzini D, Caniato F, Ronchi S, Spina G (2012) A transaction costs approach to purchasing portfolio management. Int J Oper Prod Manag 32:1015-1042

Luzzini D, Longoni A, Moretto A, Caniato F, Brun A (2014) Organizing IT purchases: Evidence from a global study. J Purch Supply Manag 20:134-155

March JG, Simon HA (1958) Organizations. Blackwell, Cambridge, MA

Matthyssens P, Faes W (1997) Coordinating Purchasing: Strategic and Organizational Issues: Relationships and Networks in International Markets. Elsevier, London, UK

Maylor H, Turkulainen V (2019) The concept of organizational projectification: past, present and beyond? International Journal of Managing Projects in Business forthcoming

Mintzberg H (1983) Structure in fives: Designing effective organizations. Prentice Hall, Englewood Cliffs, NJ

Monczka RM, Trent RJ (1991) Global sourcing: a development approach. Iinternational Journal of Purchasing and Materials Management 27:2-8

Nadler DA, Tushman ML (1997) Competing by design - the power of organizational architecture. Oxford University Press, New York

Narasimhan R, Carter JR (1990) Organization, communication and coordination of international sourcing. Int Mark Rev 7:6-20

Pagell M (2004) Understanding the factors that enable and inhibit the integration of operations, purchasing and logistics. J Oper Manag 22:459-487

Piekkari R, Plakoyiannaki E, Welch K (2010) 'Good' case research in industrial marketing: Insights from research practice. Ind Mark Manage 40:109-117

Procurement Strategy Council (ed) (2013) Procurement Organizational Structure: Aggregate Trends

Quintens L, Pauwels P, Matthyssens P (2006) Global purchasing strategy: Conceptualization and measurement. Ind Mark Manage $35: 881-891$

Ramasesh RV, Browning TR (2014) A conceptual framework for tackling knowable unknown unknowns in project management. J Oper Manag 32:190-204

Revilla E, Knoppen D (2015) Building knowledge integration in buyersupplier relationships - The critical role of strategic supply management and trust. Int J Oper Prod Manag 35:1408-1436

Roehrich J, Lewis M (2014) Procuring complex performance: implications for exchange governance complexity. Int J Oper Prod Manag 34:221-241

Rozemeijer F, van Weele A, Weggeman M (2003) Creating corporate advantage through purchasing: Toward a contingency model. J Supply Chain Manag 39:4-13

Schiele H, Horn P, Vos B (2011) Estimating cost-saving potential from international sourcing and other sourcing levers: Relative importance and trade-offs. Int J Phys Distrib Logist Manag 41:315-336

Schleper MC, Blome C, Stanczyk A (2020) Archetypes of sourcing decision-making The influence of contextual factors on consensus, argumentation and cabal. Int J Oper Prod Manag 40:117-143

Schneider L, Wallenburg CM (2013) 50 Years of research on organizing the purchasing function: Do we need any more? J Purch Supply Manag 19:144-164

Sheth JN, Sharma A (1997) Supplier relationships - Emerging issues and challenges. Ind Mark Manage 26:91-100
Stanczyk A, Foerstl K, Busse C, Blome C (2015) Global sourcing decision-making processes: Politics, intuition, and procedural rationality. J Bus Logist 36:160-181

Storbacka K (2012) Strategic account management programs: Alignment of design elements and management practices. J Bus Indust Market 27:259-274

Swoboda B, Schlüter A, Olejnik E, Morschett D (2012) Does centralising global account management activities in response to international retailers pay off? Manag Int Rev 52:727-756

Terpend R, Tyler BB, Krause DR, Handfield RB (2008) Buyer-supplier relationships: Derived value over two decades. J Supply Chain Manag 44:28-55

Toulan O, Birkinshaw J, Arnold D (2006) The role of interorganizational fit in global account management. Int Stud Manag Organ 36:61-81

Trautmann G, Bals L, Hartmann E (2009a) Global sourcing in integrated network structures: the case of hybrid purchasing organizations. J Int Manag 15:194-208

Trautmann G, Turkulainen V, Hartmann E, Bals L (2009b) Integration in the global sourcing organization - an information processing perspective. J Supply Chain Manag 45:57-74

Trent RJ, Monczka RM (2003a) International purchasing and global sourcing-what are the differences? J Supply Chain Manag 39:26-36

Trent RJ, Monczka RM (2003b) Understanding integrated global sourcing. Int J Phys Distrib Logist Manag 33:607-662

Trent RJ, Monczka RM (2005) Achieving excellence in global sourcing. MIT Sloan Manag Rev 47:24

Turkulainen V, Ketokivi M (2012) Cross-functional integration and performance - what are the real benefits? Int J Oper Prod Manag 32:447-467

Turkulainen V, Swink ML (2017) Supply chain personnel as knowledge resources for innovation - - a contingency view. J Supply Chain Manag 53:41-59

Turkulainen V, Kujala J, Artto K, Levitt R (2013) Organizing in the context of global project-based firm - the case of sales-operations interface. Ind Mark Manage 42:223-233

Turkulainen V, Kauppi K, Nermes E (2017) Institutional Explanations - Missing link in operations management? Insights on supplier integration. Int J Oper Prod Manag 37:1117-1140

van de Vijver M, Vos B, Akkermans H (2011) A tale of two partnerships: Socialization in the development of buyer-supplier relationships. J Supply Chain Manag 47:23-43

Vanpoucke E, Vereecke A, Boyer KK (2014) Triggers and patterns of integration initiatives in successful buyer-supplier relationships. J Oper Manag 32:15-33

Vesalainen J, Kohtamaki M (2015) Toward a typological view of buyer-supplier relationships: Challenging the unidimensional relationship continuum. Ind Mark Manage 49:105-115

Villena VH, Revilla E, Choi TY (2011) The dark side of buyer-supplier relationships: A social capital perspective. J Oper Manag 29:561-576

Wieland A, Bals L, Mol MJ, Handfield RB (2020) Overcoming blind spots in global sourcing research: Exploiting the cross-sections between supply chain management and international business. J Intern Manag 26:100709

Yan T, Dooley KJ (2013) Communication intensity, goal congruence, and uncertainty in buyer-supplier new product development. J Oper Manag 31:523-542

Yan T, Dooley KJ (2014) Buyer-supplier collaboration quality in new product development projects. J Supply Chain Manag 50:59-83

Yin RK (2009) Case Study Research - Design and Methods, Revised. Sage, Thousand Oaks, CA

Publisher's Note Springer Nature remains neutral with regard to jurisdictional claims in published maps and institutional affiliations. 